
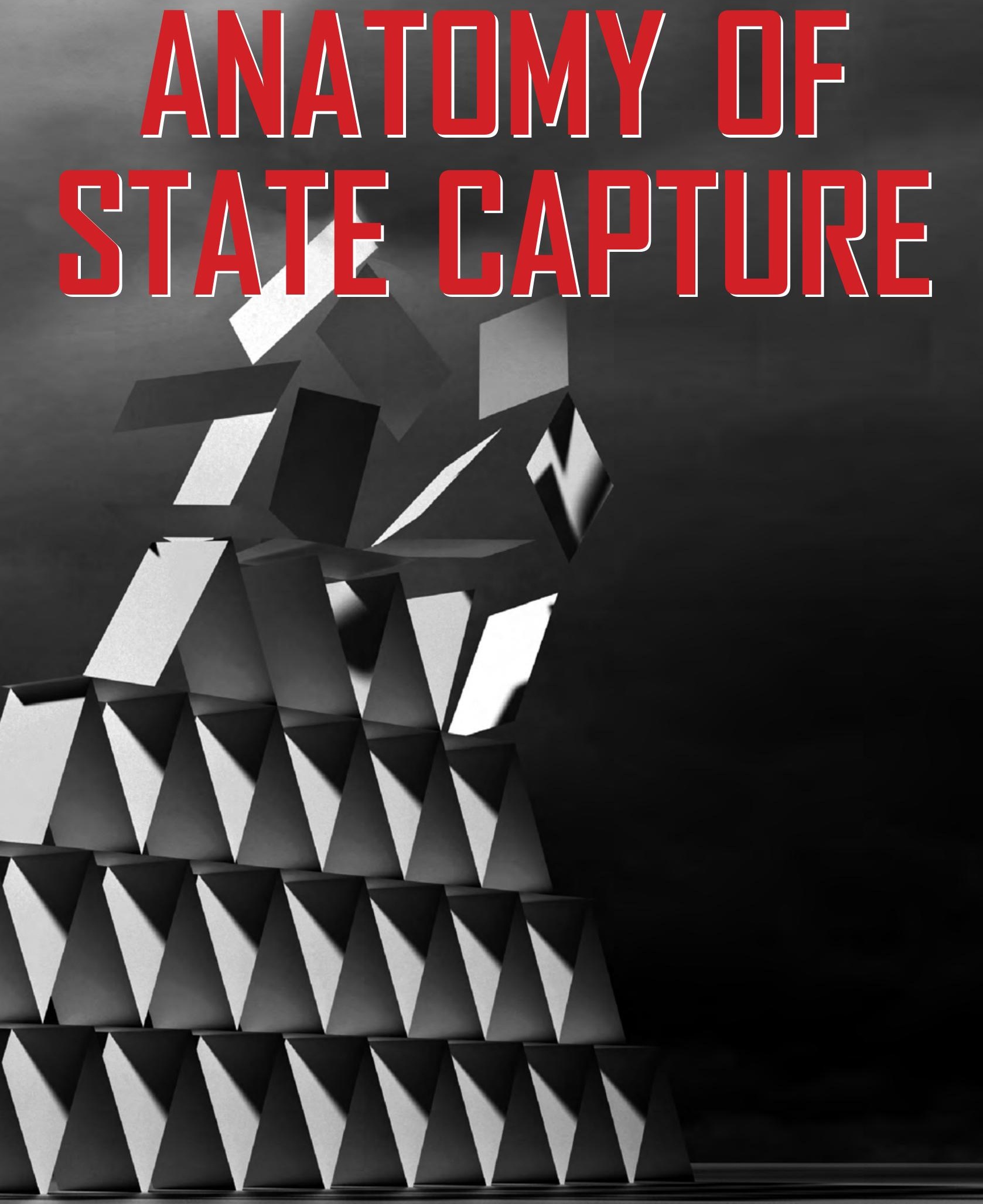

Nina Callaghan, Rabyn Foley and Mark Swilling (EDITuRS) 


\section{STATE CAPTURE AND ZUMA'S CRIMINAL JUSTICE AGENDA}

David Bruce, David Lewis and Gareth Newham ${ }^{1}$

\subsection{INTRODUCTION: THE LEGAL TRAVAILS OF JACOB ZUMA}

When he became President on 9 May 2009, and assumed overall command of SA's state machinery, Jacob Zuma had already been involved in a prolonged battle with key agencies of the criminal justice system. In November 2002, press reports indicated that Zuma, who was Deputy President of South Africa at the time, was one of those being investigated on corruption charges linked to the arms deal (Holden, 2008). Initially, for reasons probably related to his position in government and the ANC, the NPA decided not to include him in the list of those charged in respect of the matter, notwithstanding the fact that he was also strongly implicated in the indictment against his alleged accomplice, Schabir Shaik (High Court of South Africa: Natal Provincial Division, 2005; SCA, 2006). Zuma was first charged with corruption in June 2005 after Shaik had been convicted of corruption and fraud (Holden, 2008).

In the period since, Zuma's lawyers have been unrelenting in trying to ensure that Zuma does not have to stand trial. Following a series of motions by Zuma's lawyers, the charges lodged in 2005 were struck from the roll by the Pietermaritzburg High Court in September 2006 (High Court of South Africa: Natal Provincial Division, 2008). However the High Court judgment was overturned on appeal (SCA, 2009) and new charges were brought by the NPA in late December 2007, ten days after Zuma had been elected as ANC President. Acting National Director of Public Prosecutions (NDPP) Mokotedi Mpshe withdrew these charges on 6 April 2009, shortly before the 2009 general election. This followed submissions by Zuma's lawyers including the provisions of tapes ('the spy tapes') showing political interference in the NPA decision regarding the timing of the charges against Zuma. During this period, Zuma had also been charged (in December 2005) and acquitted (in May 2006) for the rape of a 31-year-old woman (High Court of South Africa: Witwatersrand Local Division, 2006).

1 This chapter is a condensed version of report submitted by Corruption Watch and the Institute for Security to the Zondo Commission in April 2019. See Corruption Watch and the Institute for Security Studies, State capture and the political manipulation of criminal justice agencies - Submission to the judicial commission of inquiry into allegations of state capture, April 2019 (Corruption Watch and Institute for Security Studies, 2019). 
During his period in office as President, whether or not he would stand trial for corruption continued to be the subject of ongoing contestation through the courts (SCA, 2012, 2014b, 2017). Allegations have been made that he was abetted by senior officials in the NPA, notably Nomgcobo Jiba in her role as acting NDPP, in obstructing some of the litigation against him, though different courts have reached different conclusions on her culpability in this regard (SCA, 2012, 2014b; High Court of South Africa: North Gauteng, 2016; SCA, 2018). Zuma is no longer President, but his legal travails continue. After the High Court in 2016 set aside Mpshe's 2009 decision to withdraw the corruption charges against Zuma, and Zuma's appeal against the decision failed in October 2017 (SCA, 2017), the NPA reinstated charges against Zuma in March 2018 (Pather, 2018). After a further series of unsuccessful legal manoeuvres, at the end of April 2020 Zuma's legal team finally announced that they had abandoned their intended appeal to the Constitutional Court for a permanent stay of prosecution (Khumalo, 2020). As of May 2020, the case against Zuma is due to proceed in the KwaZulu-Natal High Court in June.

Mobilising support around him and enabling himself to become the preferred candidate for those who were frustrated with then President Thabo Mbeki appears to have served as Zuma's best instrument for protecting himself from being held accountable for his alleged corruption. Whatever the motives of those who mobilised for Zuma to become ANC President in 2007, and thus President of South Africa in 2009, for Zuma himself this appears to have firstly served as a way of ensuring that he stayed out of jail. Notwithstanding that his oath of office committed him to 'obey, observe, uphold and maintain the Constitution and all other law of the Republic' (Republic of South Africa, 1996), given the facts available to us it is reasonable to believe that Zuma did not view the principles of equality before the law embodied in the Constitution, in favourable terms. Instead, he appears to have deemed it necessary to ensure that the criminal justice system was subordinated to his personal interests.

\subsection{MANIPULATION OF CRIMINAL JUSTICE AGENCIES BY THE EXECUTIVE UNDER ZUMA}

Following his election as President, it appears that Zuma's interest in protecting himself against prosecution came to be aligned with the broader project that has come to be known as state capture. The manipulation of criminal justice agencies contributed to this through:

- Ensuring impunity - protecting Zuma, his family, and other allies and associates from prosecution. This extended to generalised impunity for the political class and those associated with state capture. 
- Promoting Zuma's control of the ANC - Zuma's control of the ANC was the pivotal enabler of state capture. State intelligence capacity, including the SAPS crime intelligence division, were used to promote control of the ANC for Zuma and his allies.

- Neutralising criminal justice officials who posed a threat to impunity, and administrators and politicians, including members of his own Cabinet, who did not cooperate with the state capture agenda.

The evidence indicates that Zuma and members of his Executive played a central role in this manipulation, most notably through their ability to influence the appointment and removal of key officials of the criminal justice agencies including the SAPS, the Directorate for Priority Crime Investigation ('the Hawks') and NPA and Independent Police Investigative Directorate (IPID).

\subsection{RICHARD MDLULI AND THE MANIPULATION OF THE SAPS CRIME INTELLIGENCE DIVISION}

Zuma showed his hand shortly after his appointment as President. On 1 July 2009, less than two months after he had assumed office, Richard Mdluli was appointed as Head of the SAPS Crime Intelligence Division. In terms of SAPS regulations, the head of crime intelligence should have been appointed by the National Commissioner. ${ }^{2}$ Instead Mdluli was appointed irregularly by a panel of politicians headed by the Minister of Police, Nathi Mthethwa and consisting of three other Zuma aligned Ministers, Siyabongwa Cwele (State Security), Malusi Gigaba (Home Affairs) and Susan Shabangu (Energy Resources and previously Deputy Minister of Police) (City Press, 2011a).

Mdluli's appointment was prioritised over that of a new SAPS National Commissioner. At that time, the SAPS had been under an acting National Commissioner, Tim Williams, for just short of 18 months. When Zuma appointed Bheki Cele as National Commissioner on 29 July 2009, Cele was faced with Mdluli's promotion to head SAPS crime intelligence as a fait accompli.

Despite also being a KwaZulu-Natal based politician, Cele was not one of Zuma's close political allies. However, at that time he was aligned with Zuma's populist agenda for

2 See Chapter 4, and in particular sections 43, 44 and 45 of the Regulations for the South African Police Service, No R. 973, 12 September 2008 (Department of Safety and Security, 2008). It may be noted that Section 2(1) of the 2008 regulations provided that: "The Minister may, if circumstances justify it, approve a deviation from any provision of these Regulations, and may authorise such deviation with retrospective effect for purposes of equality." It appears unlikely that the appointment of Mdluli may be seen as one which is justified in terms of this provision. Even if so, it fell clearly outside the established procedures. 
getting tough on crime. During Zuma's tenure in office the capacity of criminal justice agencies to deal with corruption was consistently weakened, creating a permissive environment for corruption. Most notably during his early period in office, Zuma and his allies projected themselves as 'tough on crime' through promoting more forceful 'militarised' policing. During his tenure as a member of KwaZulu-Natal Provincial Executive (2004-2009), Cele had encouraged more liberal use of lethal force by police (Kathree-Setiloane, 2013). But Cele's role in Zuma's strategy appears to be secondary to that of Mdluli.

In addition to the priority given to appointing Mdluli and the irregular process followed, enormous effort would be expended on ensuring Mdluli's impunity. Evidence showed that it was likely that Mdluli had instigated the February 1999 murder of Tefo Ramogibe, the husband of a woman that Mdluli had been married to in customary law (North Gauteng High Court, 2013; Breytenbach \& Brodie, 2017). There were also cases involving intimidation, kidnapping, assault, assault with intent to do grievous bodily harm and attempted murder, that were linked to the Ramogibe matter ('the related charges'). At the time of the alleged crimes Mdluli was the head of detectives at the Vosloorus police station. This was probably the reason why the investigation was abandoned. The investigation was re-opened after he became Head of Crime Intelligence. Mdluli was arrested in March 2011 and placed on suspension due to the murder charges. He was arrested a second time, in September 2011, on charges of corruption and fraud linked to alleged abuse of crime intelligence funds. The latter allegations against Mdluli would be the subject of detailed evidence to the Zondo Commission in $2019 .^{3}$

The corruption charges against Mdluli were withdrawn, allegedly irregularly, in early December 2011 by Lawrence Mrwebi, a Special Director of Public Prosecutions and head of the Specialised Commercial Crime Unit. Mwerbi had been appointed by Zuma on 1 November 2011. It is alleged that Nomgcobo Jiba, who was appointed by Zuma as acting National Director of Public Prosecutions on 28 December 2011, further shielded Mdluli by failing to review Mrwebi's decision despite the controversy that it caused (SCA, 2014a, paras. 32-42). In March 2012, Police Minister Nathi Mthethwa also allegedly pressurised the then SAPS acting National Commissioner to withdraw Mdluli's suspension (amaBhungane, 2012; City Press, 2012; SCA, 2014a). In relation to the withdrawal of the murder charges there were also peculiarities. During the same period, both the Gauteng Director of Public Prosecutions and the inquest magistrate of Boksburg also acted in an unusual manner in relation to the evidence of 
murder against Mdluli (North Gauteng High Court, 2013; SCA, 2014a; Breytenbach \& Brodie, 2017).

After being reinstated at the end of March 2012, Mdluli was suspended again in early June following a successful court application by a civil society organisation. No further action was taken against Mdluli in respect of the murder or any of the related charges for several years afterwards. In January 2018, weeks before Zuma's resignation as President, Mdluli agreed to take early retirement (News24, 2018a). By this point Mdluli had been on suspension with full pay and benefits for six and a half years altogether without disciplinary action being taken against him in relation to any of the evidence of wrongdoing.

However, partly as a result of litigation, the charges against Mdluli had not fallen away entirely (SCA, 2014a, paras. 2, 32-42). In October 2016 Mdluli and a co-accused appeared in court again on various charges including intimidation, kidnapping, and assault with intent to do grievous bodily harm (Masilela, 2016). The two accused were convicted on most charges in July 2019 (Chabalala, 2019), though an appeal against the Constitutionality of the intimidation act resulted in the intimidation convictions being overturned and as of May 2020 final sentence has not as yet been given. As a result of the findings of the inquest court, the murder charges however have not been pursued further. There has also been no progress in prosecuting the corruption charges against him.

Why did Zuma and members of his Executive attach so much importance to appointing Mdluli and retaining him as Head of Crime Intelligence? It is possible that the association between Mdluli and Zuma goes back to 2006 when Mdluli, as a Gauteng Deputy Provincial Commissioner, would have had overall authority over the detectives who investigated the failed rape case against Zuma (amaBhungane, 2012). It also appears that an alliance between Nomgcobo Jiba and Mdluli began in the $2007 / 8$ period when both were associated with efforts to undermine the Scorpions corruption investigation against then SAPS National Commissioner Jackie Selebi (Mail \& Guardian, 2009; City Press, 2011b). Jiba's favourable relationship with Mdluli may have contributed to Jiba becoming Zuma's favoured senior NPA official. Not only did he appoint her as acting NDPP for a full 21 months, but there is information suggesting that even after this point she was the NPA official who was most favoured and trusted by him (Zondo Commission, 2019a).

After being suspended in December 2007, Jiba faced disciplinary charges in the NPA regarding her involvement in the Selebi case. Mdluli, who as Gauteng Deputy Provincial Commissioner had oversight over SAPS Crime Intelligence, filed an affidavit in her support. This revealed that the SAPS had been monitoring the 
telephone conversations of Scorpions Head Leonard McCarthy. It is likely that it was Mdluli who later unlawfully provided Zuma's lawyers with copies of the 'spy tapes' these being recordings of some of McCarthy's telephone conversations. These proved useful to Zuma's lawyers in persuading Acting NDPP Mokotedi Mpshe to withdraw the corruption charges against Zuma in April 2009.

The power of spy masters is often related to what they know about the people that they work for. Whether this was part of Mdluli's hold on Zuma is unknown. It appears likely however that it was not that Zuma felt that he owed Mdluli a debt of gratitude in relation to the spy tapes, or that Zuma feared what Mdluli might do with information that he had about him. Instead, Mdluli's key role was likely to have involved using crime intelligence personnel and resources to assist Zuma in retaining control of the ANC and assisting Zuma in helping to neutralise threats to the impunity against prosecution that he and his allies appear to have enjoyed (Pauw, 2017, p. 234).

Notwithstanding his past as a policeman appointed in the apartheid era, given the facts available to us, it is reasonable to conclude that Richard Mdluli was seen by Zuma as a key ally and instrument. Zuma's career in the ANC in exile was largely in the intelligence sector. The fact that Zuma chose to rely on Mdluli may be seen to reflect Zuma's appreciation of the 'uses' of intelligence. This is consistent with Zuma's misuse of other intelligence agencies as documented by the high-level review panel on the State Security Agency (SSA) that was appointed by President Ramaphosa in June 2018 (The Presidency, 2018). The panel found that the SSA's Special Operations component had 'become a parallel intelligence structure serving a faction of the ruling party and, in particular, the personal political interests of the sitting President of the party and country' (High-Level Review Panel on the SSA, 2018, p. 66).

\subsubsection{Neutralising the Hawks}

At the time when Mdluli was appointed, Zuma's Minister of Police, Nathi Mthethwa, was also required to appoint the first head for the Hawks. Mthethwa had been instrumental in appointing Mdluli. But the Hawks appointment was a more high profile one. The creation of the Hawks had been shrouded in controversy and the launch of the unit in early July 2009 would involve a high level of media attention. Zuma and his allies had been instrumental in the demise of the Directorate for Special Operations (the Scorpions), the predecessors to the Hawks. One justification for disbanding the Scorpions was that they had allegedly been used to neutralise Zuma and other political opponents of former President Thabo Mbeki. For purposes of their own credibility, Zuma and Mthethwa therefore needed to appoint someone who might credibly be seen as independent. Zuma would have been likely to have preferred to appoint someone who would ensure that he, at the very least, was protected against 
investigation. It may be that he believed that Anwa Dramat, who had also served time on Robben Island, would conform to this requirement.

More than two years later, on 23 October 2011 a front-page story appeared in the Sunday Times alleging that Dramat and Hawks Gauteng Head, Shadrack Sibiya, had been involved in the illegal renditions of six Zimbabweans who were handed over to the Zimbabwean police in November 2010. Allegedly two of the Zimbabweans were killed by members of the Zimbabwe police after they had been handed over (Sunday Times Investigation Staff, 2011). Six weeks later another set of allegations appeared. On 11 December 2011 a front-page story in the Sunday Times alleged that the Cato Manor Organised Crime Unit, a unit of the Hawks in KwaZulu-Natal, had been linked to the extra-judicial execution of numerous crime suspects. A key aspect of the allegations was that Johan Booysen, the Head of the Hawks in KwaZulu-Natal, was complicit in these activities. ${ }^{4}$

Both of these stories emanated, at least in part, from information that was 'leaked' to the Sunday Times from within the SAPS. There is good evidence that the renditions 'leak' against Dramat and Sibiya emanated from SAPS crime intelligence (Sole, 2015). One contention is that the motivation behind the initial leak in October 2011 was the fact that Sibiya, with the support of Dramat, were investigating the murder allegations against Richard Mdluli (Thamm, 2018). There is also evidence that Mdluli worked with Berning Ntlemeza in trying to ensure that Dramat was removed from office so that Ntlemeza could replace Dramat (Bateman, 2016; Evans, 2016; Thamm, 2017). It may be that the attempt to incriminate Dramat was initiated by Mdluli and Ntlemeza or that it was initiated at the behest of the Executive. Based on his experience of being investigated by the Scorpions, Zuma is likely to have been concerned about the type of threat that the Hawks might pose to him, particularly if they operated independently. Once Dramat started showing such signs, this would have motivated Zuma and his second Minister of Police (in May 2014 Zuma replaced Nathi Mthethwa with Nathi Nhleko) to take action against him.

Dramat would only face disciplinary action in late 2014, and Sibiya in January 2015, three years after the allegations against them first appeared. Dramat has stated that Nhleko suspended him in late 2014 after Dramat called for action on certain case dockets 'involving very influential persons' (Sole, Brümmer \& Evans, 2015). After Dramat's suspension, Ntlemeza was appointed as Head of the Hawks, initially in an

$4 \quad$ The article was removed from the Sunday Times and an apology to Booysen was published by the editor of the Sunday Times (Siqoko, 2018) though the Sunday Times editor from the time when the original article was published has defended its publication (News24, 2018a). An image of the article is available (Sunday Times, 2018) and the text of the article is also available (Hofstatter, wa Afrika \& Rose, 2011). 
acting capacity in late December 2014 (Lindeque, 2014; Evans, 2016). In September 2015, he became the permanent head of the Hawks. As with Mdluli's appointment, the process was irregular (Thamm, 2016; Mashego, 2017c). And as with Mdluli, Ntlemeza's appointment appears overtly to have been intended to ensure that Zuma, and those associated with state capture, were shielded from justice. One feature of Ntlemeza's term of office was numerous questionable senior promotions and appointments resulting in the overall weakening of the Hawks capacity to investigate corruption.

In contrast to Dramat and Sibiya, the publication of the allegations against Booysen and the Cato Manor unit led to action far more quickly. Prosecutions were instituted against them, and Booysen and the Cato Manor unit members were suspended from the SAPS, within six to nine months of the publication of the Sunday Times story. It is alleged that the allegations in the Sunday Times emanated from information provided by crime intelligence, though the Sunday Times has also disputed these allegations (Pitchford, 2016, pp.101-103). Whichever account is true, it is apparent that the Hawks investigators who were appointed to investigate the Cato Manor allegations after they had been published, had links to Richard Mdluli (Pitchford, 2016, p. 106).

There may have been some substance to the allegations against the members of the Cato Manor unit, but it is doubtful whether the pattern of questionable killings linked to the Cato Manor unit was the real reason why the matter was treated as an investigative and prosecutorial priority. Instead, it appears that the motivation was to provide a pretext for taking action against Booysen in order to neutralise certain corruption investigations of which he was in charge. These included an investigation against an associate of Zuma's family, Thoshan Panday, in a case that also implicated the KwaZulu-Natal SAPS Provincial Commissioner (Underhill, 2015; Wicks, 2015).

\subsubsection{Securing Control of the ANC}

Given that Crime Intelligence works under a veil of secrecy, the manner in which Crime Intelligence worked to favour the Zuma faction in the ANC may never be fully known. However, this may have included surveillance of ANC members enabling Zuma to obtain advance warning of disloyalty and gather information on rivals (amaBhungane, 2012; Eyewitness News, 2012; Sole \& Evans, 2012; SCA, 2014a; Pauw, 2017). It is also alleged that Crime Intelligence members linked to Mdluli played a major role in trying to ensure that the outcome of ANC elective conferences was favourable to Zuma and his allies both in 2012 at Mangaung (Pauw, 2017, pp. 306-307) and again five years later (though unsuccessfully) in the build-up to the December 2017 Nasrec conference in Johannesburg (Mashego, 2017b, 2017a; Pauw, 2017). Although Mdluli was on suspension at the time of these conferences, it is understood that he retained considerable authority in SAPS crime intelligence (Pauw, 2017, pp. 306-307). 


\subsection{ENSURING INFLUENCE OVER THE NPA}

In addition to being able to exert influence over the Hawks, Zuma exerted his influence over the highest level of the NPA, apparently to ensure that he and his allies were not prosecuted. Considerations about the credibility of appointees were completely disregarded when Zuma appointed a new NDPP, Menzi Simelane, on 25 November 2009. A few days before this, former NDPP Vusi Pikoli had agreed to withdraw legal action contesting his removal from office and reached a financial settlement with government (SA News, 2009). Simelane had been appointed as Director General (DG) of the Department of Justice in June 2005, five months after Pikoli had been appointed as NDPP (SCA, 2011, para. 15). At the time when he was appointed as DG, Simelane was 38 years old and had practised as an advocate for only two years (SCA, 2011, para. 8). He was appointed as a Deputy NDPP by Zuma six weeks before he was appointed as NDPP.

In 2007, conflict had arisen between Mbeki and his Minister of Justice Bridget Mabandla and Pikoli over Pikoli's intentions to have Jackie Selebi arrested on the basis of corruption charges. Mbeki suspended Pikoli and appointed an official inquiry, headed by Frene Ginwala, into Pikoli’s fitness for office. Ginwala’s November 2008 report made some critical comments about Pikoli but confirmed that he was 'fit and proper' to serve as NDPP and recommended his reinstatement (SCA, 2011, para. 22). Notwithstanding the report, Kgalema Motlanthe, who replaced Mbeki as President in September 2008, decided to remove Pikoli from office.

The great irony of Zuma's appointment of Simelane in Pikoli's place in November 2009, was that the Ginwala Inquiry report was far more critical of Simelane than it had been of Pikoli. As DG of the Department of Justice, Simelane played a major role in drafting government's submissions to the inquiry (SCA, 2011, para. 18). The report stated that Simelane's "conduct left much to be desired" that his "testimony was contradictory and without basis in fact or in law" and that several of the allegations that were levelled against Pikoli in the submissions that Simelane had prepared were "baseless" (SCA, 2011, para. 23). It was widely believed that, due to the possibility of prosecution that he faced, "Zuma could simply not risk having an independentlyminded NDPP" (Democratic Alliance, 2009) and that this is why Simelane was selected for appointment as NDPP.

Within a month of his appointment as NDPP, the DA would bring a court action for Zuma's appointment of Simelane to be declared constitutionally invalid. Two years later, in December 2011, the Supreme Court of Appeal (SCA) confirmed that Simelane's appointment was irrational and therefore invalid. Zuma was then obliged to place Simelane on special leave pending consideration of the SCA's finding by the 
Constitutional Court. In December 2010, probably anticipating Simelane's departure, Zuma made another significant move, appointing Nomgcobo Jiba as a Deputy NDPP. This was somewhat unusual as it involved promoting her by two levels, bypassing the Director level. When she was promoted, she was already indebted to Zuma. Three months earlier, in September 2010, Zuma expunged the criminal record of her husband Booker Nhantsi for stealing R193000 worth of trust funds from a client while practising as an attorney. Available information indicates that what may have recommended Jiba to Zuma was that she already had an association with Mdluli. Both were linked with efforts to neutralise the Scorpions' investigation against Jackie Selebi (Mail \& Guardian, 2009; City Press, 2011b).

Jiba's appointment as acting NDPP meant that, in the space of little more than a year, she had been promoted by three levels. Her tenure as acting NDPP would last a full 21 months. It was only in the face of litigation compelling him to make a permanent appointment that Zuma replaced her with Advocate Mxolisi Nxasana at the end of August 2013 (Mail \& Guardian, 2009). During her tenure as acting NDPP, Jiba was accused of having not only favoured Zuma directly (SCA, 2012), but also protecting Mdluli from criminal prosecution (SCA, 2014a, para. 27), and of authorising poorly motivated charges against Booysen (High Court of South Africa: Kwazulu-Natal, 2014). Jiba has remained adamant that she did nothing wrong, but nothing done by her during her term of office and subsequent tenure in the NDPP ever threatened the Zuma impunity agenda (Chauke, 2019). It has been alleged that, even after she was no longer acting NDPP, she remained Zuma's most favoured and trusted NPA official (Zondo Commission, 2019a). During her time of influence, the NPA's general approach appears to have been to avoid prosecuting any significant corruption cases linked to Zuma, his family and their associates.

\subsection{CRIMINAL JUSTICE LEADERSHIP INSTABILITY DURING ZUMA'S TERM AS PRESIDENT}

During the remainder of his term of office, Zuma and his associates appear to have faced difficulty with finding leaders for criminal justice agencies who both seemed credible and would cooperate in ensuring his impunity. The appointment of those apparently most likely to fulfil his agenda proved indefensible in the courts in various instances. On the other hand, a number of those appointed appear to have resisted pressure to compromise themselves in order to serve his interests. Zuma and his collaborators ultimately had to rely on bullying tactics and the offer of financial settlements to remove Dramat and Mxolisi Nxasana from office. Attempts to remove Robert McBride as Head of IPID, apparently after he refused to cooperate in implicating Dramat and Sibiya in the illegal renditions case, were defeated in the courts. 
In other cases, Zuma's predilection for appointing senior criminal justice officials who lacked meaningful experience, proved to be a liability for other reasons. The killing of 34 men by police at the Lonmin Marikana mine on the afternoon of 16 August 2012 can be seen as partly a result of Zuma's decision to appoint Riah Phiyega, who had no policing background, as SAPS National Commissioner. There are also questions about whether Phiyega also facilitated Zuma's impunity agenda. After being appointed in June 2012, Phiyega was suspended in October 2015 to face a board of inquiry on the basis of the recommendations of the Marikana Commission of Inquiry (eNCA, 2015b). Richard Mdluli's suspension overlaps with the 40-month period during which Riah Phiyega was SAPS National Commissioner. Despite a court order that disciplinary action be taken against Mdluli, Phiyega failed to act, thereby enabling Mdluli to remain on suspension with his full pay and benefits intact (eNCA, 2015a; Mahlangu, 2018).

For various reasons, Zuma's impunity agenda therefore resulted in considerable instability in the leadership of criminal justice agencies. One prominent feature of the eight years and eight months in which Zuma served as President was the suspension or removal of senior criminal justice officials prior to the completion of their full terms of office. As reflected in Table 13.1 below, at least nine senior criminal justice officials appointed or promoted during Zuma's term of office served periods of suspension or special leave while eight were removed from office.

The instability had multiple causes. These included action by the Executive intended to advance impunity, including taking disciplinary action against officials following 'leaks'. Another cause of instability was the disposition of the Executive to appoint individuals who were unsuitable for office or to use irregular appointment processes. Both Simelane and Ntlemeza were removed from office as a result of litigation contesting their appointment. The removal of NDPP Shaun Abrahams (appointed June 2015) in August 2018 also originated in litigation. In this case the court found that the removal of his predecessor, Mxolisi Nxasana, was an abuse of Presidential power. As a result, Abraham's appointment was also invalid (Constitutional Court of South Africa, 2018).

One by-product of this instability and manipulation was wasteful expenditure of various kinds including poorly motivated state expenditure on litigation, the salaries of those serving periods of suspension, and the liberal use of resources for the purpose of securing the removal from office of officials - including Pikoli, Dramat and Nxasana - through financial settlements. The scale of the leadership instability is not fully reflected in the above table. During the period of Mdluli's suspension, SAPS Crime Intelligence went through a series of acting Heads. Likewise, during 


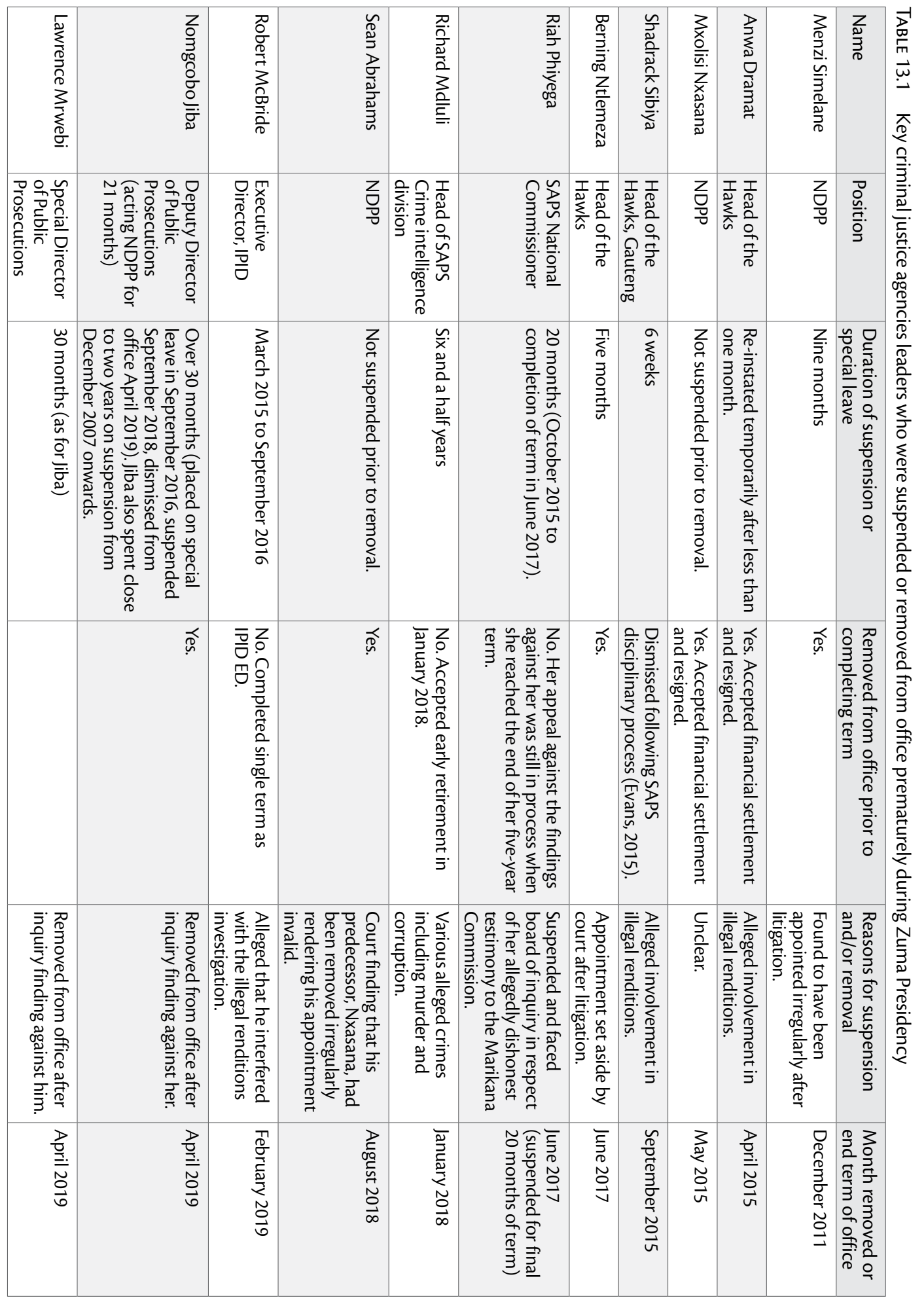


Phiyega's suspension, Khomotso Phahlane, who took over from her as acting National Commissioner, was also suspended on full pay on the basis of corruption allegations against him, and was replaced by another acting National Commissioner who served for five months until Zuma appointed a new SAPS National Commissioner during the last months of his Presidency in November 2017 (Gous, 2017; Mail \& Guardian, 2017).

\subsection{NEUTRALISATION OF OPPONENTS IN POLITICAL OFFICE AND THE ADMINISTRATION}

The extent of the Zuma Executive's manipulation of criminal justice system can also be seen in steps that were taken to neutralise opponents in political office and the public service. These resemble the 'leak' targeted at both Dramat and Sibiya and the steps taken against Booysen. As indicated, there are allegations and evidence that SAPS Crime Intelligence, under Mdluli's influence, played a critical role in both of these cases. As discussed in another chapter, the 'leaks' strategy was also used against senior officials at SARS, as well as Pravin Gordhan, a Cabinet member who served inter alia as Minister of Finance but was seen as an obstacle to aspects of the state capture project. In respect of the SARS leaks, however, it appears that the State Security Agency (SSA), rather than crime intelligence, was the primary role player.

Whilst disregarding serious corruption cases, the Hawks and NPA appeared to prioritise cases in which Gordhan might be implicated, even if the evidence was insubstantial. In October 2016, Gordhan, as well as Ivan Pillay and Oupa Magashula, were summonsed to appear in court on charges of fraud related to allegedly irregularities in the rehiring of Pillay after his retirement. On the day before their scheduled court appearance the charges were withdrawn (News24, 2016; PMG, 2016; Tandwa, 2016; Van Wyk, 2016). Earlier in 2016, while Gordhan was preparing to deliver his budget speech, the Hawks submitted a set of poorly considered questions on the alleged SARS 'rogue unit' to him in what was understood to be a form of harassment and intimidation (Munusamy, 2016; Du Toit, 2018; Hunter, 2018).

In March 2016, at the same time that the Hawks were pursuing Gordhan in relation to the 'rogue unit', the NPA announced that Robert McBride and two others from IPID were to be charged with fraud and defeating the ends of justice relating to the IPID reports exonerating Dramat and Sibiya on the illegal rendition allegations. In November 2016 the NPA announced that it would be withdrawing the charges (Raborife, 2016). Another government official who was targeted was Glynnis Breytenbach, a senior NPA prosecutor. Breytenbach was one of those who objected to the withdrawal of the corruption charges against Mdluli. 


\section{TIPPITE TTE SGALES OF GRTITA}

\section{TIMELINE GRAPHICS KEY}

\section{Scorpions \& the Arms Deal Scorpions are launched. \\ They look into Ams Deal \& various high profile political/power elites like Jacob Zuma, Schabir Shaik, Brett Kebble, Glenn Agliotti \& Jackie Selebi. The Arms Deal investigations lead National Director of Public Prosecutions (NDPP), Bulelani Ngcuka to prosecute Schabir Shaik for fraud \& corruption - Zuma is also initially implicated, but is only charged by new NDPP Vusi Pikoli in 2005 after Shaik is convicted. Zuma also charged with raping a 31-year-old family friend in the same year. Based on these charges, Mbeki fires Zuma as vice president.}

Mdluli \& Jiba protect Zuma Zuma ally, Richard Mdluli appointed deputy provincial commissioner for Gauteng (despite his implication in a suspiciously abandoned murder case from 1999).

He oversees detectives investigating Zuma's rape case in 2006 \& also heads up investigations into the Scorpions (focusing on then Head of the elite Scorpions investigative unit, Gerrie Nel). Around the same time Nomgcobo Jiba is appointed Senior Deputy Director of Public Prosecutions in Scorpions - she is later suspended having been found assisting in the sketchy investigation into Gerrie Nel.

Zuma is let off the hook Zuma acquitted of rape charges $\&$ his Arms Deal charges are also dropped due to bungled prosecution efforts. Over the next 2 years the Arms Deal charges resurface $\&$ are dropped twice in a power struggle between Mbeki \& Zuma. Ultimately Mbeki is forced to resign as President of SA based on his alleged NPA interferences after Zuma is elected ANC president.
Seeking justice

Swaying security
Justice thwarted

Dodgy allegations \& investigations
Advocating impunity

Political shift

NR of (current) prioritised corrupt cases by year - identified by NPA with DPCI (Hawks)

Motlanthe in, Scorpions out Kgalema Motlante, supported by Zuma, takes over Presidency. In the next few months Parliament abolish the Scorpions \& Zuma's lawyers produce the 'spy tapes' showing political interference in the NPA's timing of the charges against him. Motlanthe fires NDPP Vusi Pikoli, replaces him with Acting NDPP Mokotedi Mpshe, who then withdraws Arms Deal charges against Zuma (just before 2009 general election).

\section{Zuma becomes President of} South Africes

Mdluli becomes Head of SAPS Crime Intelligence Division - appointed irregularly by a panel of politicians headed by the Minister of Police, Nathi Mthethwa. The panel includes Siyabonga Cwele (State Security), Malusi Gigaba (Home Affairs) \& Susan Shabangu (Energy Resources \& previously Deputy Minister of Police).

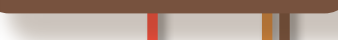

Hawks established. Mthethwa appoints Anwa Dramat as its head.

After much legal contestation over removal as NDPP, Vusi Pikoli leaves with R7.5m out-of-court settlement \& Zuma appoints Menzi Simelane NDPP

Zuma expunges criminal record of Jiba's husband, Booker Nhantsi, for stealing R193k from a client.
Mdluli's murder-related investigation is reopened. Dramat \& Sibiya (of Hawks) investigate related allegations \& other corruption allegations against Mdluli.

Nomgcobo Jiba appointed Deputy National Director of Public Prosecutions.

Moluli's crime intelligence unit conducts an illegal \& unsanctioned raid on the office of Public Protector Thuli Madonsela.

\section{1 1}

Moluli arrested \& placed on suspension (8 May) due to 1999 murder-related charges - witness intimidation \& evidence tampering unfold in court. He is also later arrested on corruption \& fraud charges linked to alleged abuse of crime intelligence funds.

\section{1 .}

Sunday Times (ST) allege Dramat \& Hawks Gauteng Head Shadrack Sibiya involved in illegal handing over of 6 Zimbabweans to Zimbabwean police.

Zuma appoints Lawrence Mrwebi as Special Director of Public

Prosecutions \& Head of the

Specialised Commercial Crime Unit. 110

Mdluli sends Zuma a letter claiming a conspiracy to oust him. He says "In the event that I come back to work I will assist the president to succeed next year", in reference to the ANC's Dec 2012 elective congress in Mangaung.
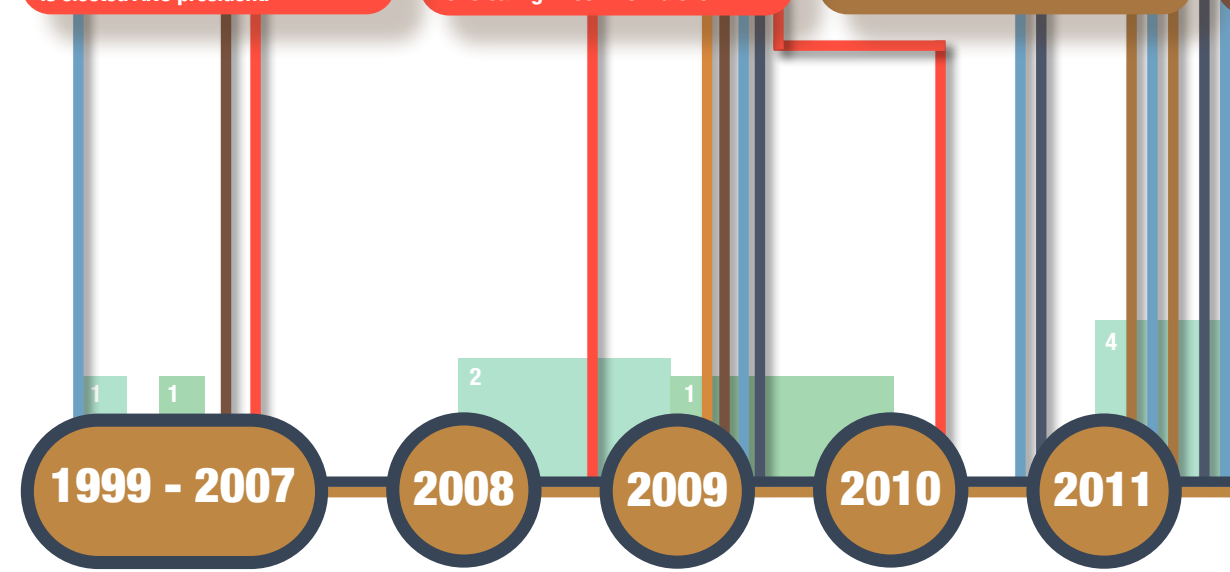

Sunday Times allege Hawks KwaZulu-Natal, Cato Manor Organised Grime Unit Head Johan Booysen is complicit to the extrajudicial execution of numerous crime suspects - at the time Booysen is investigating the SAPS R60m tender scam implicating Edward Zuma's business partner (\& close JZ ally), Thoshan Panday \& Col. Navin Madhoe.

Mrwebi withdraws corruption charges against Mdluli - no particular reason given. 2 months later Adv.

Andrew Chauke provisionally withdraws murder \& related charges to complete an inquest into the case. 111

Zuma forced to suspend Simelane based on irregular appointment allegations \& he appoints Jiba as Acting NDPP - she is to review

Mrwebi's decision on Mdluli case.

\section{1] 1}

Mdluli reinstated Head of SAPS

Crime Intelligence Division.

4 months later he is suspended again after civil society litigation.

DA need 'spy tapes' for bid to have Arms Deal charges reinstated - NPA (Jiba) \& Zuma refuse to release them \& litigation ensues - ultimately they are forced to release them.

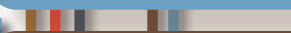

Following inquiry Cele removed \& Riah Phiyega appointed SAPS National Commissioner.

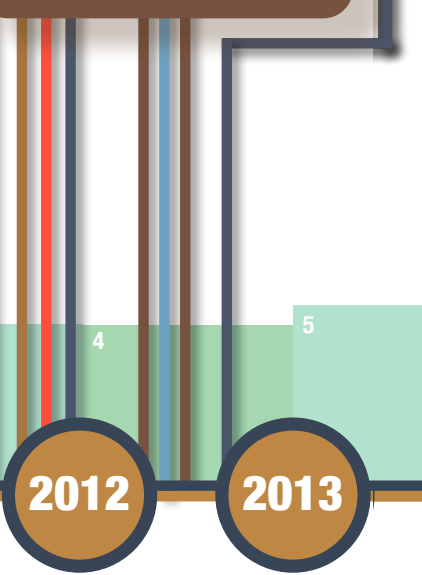




\section{JSTGE IT FATOUR OF GORRTPTON}

Booysen charged with alleged racketeering \& other crimes relating to the now disbanded Cato Manor serious \& violent crime unit 'death squad' - racketeering charges signed off by Jiba.

Facing possible litigation, Zuma is compelled to replace Jiba with Adv. Mxolisi Nxasana at the end of Aug 2013 - Jiba goes back to Deputy NDPP.

Zuma's second term \& notably Nathi Mthethwa is replaced with Nkosinathi Nhleko as Minister of Police.

Nxasana accuses Jiba of being obstructive when asked to hand over major case files which included cases against Mdluli; the so-called "Amigos" case against prominent KZN politicians; the Cato Manor 'death squad' \& the spy tapes case used to withdraw corruption charges against Zuma.

Zuma meets with Nxasana \&

threatens him with inquiries into his fitness to hold office. Nxasana later sends a letter to Zuma recommending Jiba \& Mrwebi's suspension.

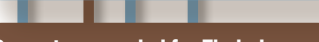

Dramat suspended for Zimbabwean rendition saga. Berning Nitemeza irregularly appointed acting Head of the Hawks - made permanent in Sept 2015.

Head of the Gauteng Hawks, Shadrack Sibiya suspended by Nhleko.

Sa

Zuma announces an inquiry into Nxasana's fitness to hold office.

Head of IPID, McBride unlawfully suspended by Nhleko for exonerating Sibiya \& Dramat

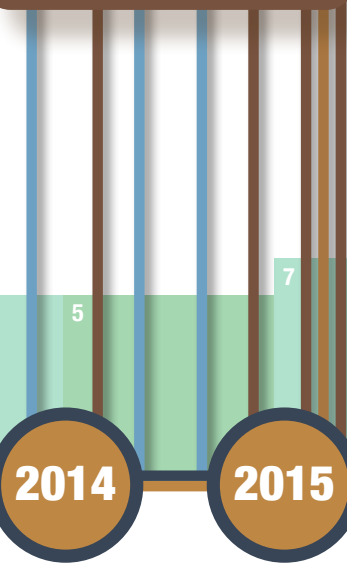

Dramat offered R3m severance

payment, plus R60k pm until he turns 60 , for his resignation.

Nxasana signs settlement agreement with president - agrees to resign as NDPP for a R17m golden handshake. He is irregularly replaced by Shaun Abrahams.

Booysen irregularly suspended once again by Nitemeza on same resurrected Cato Manor charges. He takes legal action \& his suspension is set aside 4 months later.

Abrahams declines to prosecute Jiba \& withdraws charges of perjury \& fraud.

\section{III}

Phiyega suspended, facing a board of inquiry on the basis of the recommendations of the Marikana Commission of Inquiry.

Khomotso Phahlane enters as acting national commissioner.

\section{0}

Hawks give Gordhan a set of poorly considered questions on the alleged SARS 'Rogue Unit' just before (4 days) his budget speech. On the same day NPA prosecute former Hawks Head Dramat, Major-General Shadrack Sibiya \& Capt. Lesley Maluleke on Zimbabwean rendition saga. Later McBride \& 2 others from IPID charged with fraud \& defeating the ends of justice based on their exoneration of charges against Dramat \& Sibiya.

High Court sets aside Mpshe's 2009 decision to withdraw Zuma's corruption charges.

ConCourt rules that Police Minister's decision to suspend McBride invalid \& unconstitutional. He returns to work in Oct \& by Nov NPA withdraws charges.

\section{ONLY 16 OF THE 86 PRIORITISED CORRUPT CASES IDENTIFIED WERE ENROLLED OVER 2 DECADES}

Jiba struck off the roll of advocates by the North Gauteng High Court

Mdluli \& a co-accused appear in

court again on various charges including intimidation, kidnapping. $\&$ assault with intent to do grievous bodily harm.

Pravin Gordhan, Ivan Pillay \& Oupa Magashula summonsed to appear in court over fraud charges related to alleged irregularities in rehiring Pillay after his retirement.

\section{(1)}

Under public scrutiny NPA withdraws charges against Gordhan, Pillay

\& Magashula as well as charges against McBride \& co.

$$
\text { III }
$$

Fikile Mbalula replaces Nhleko as Minister of National Police.

II I I I

Nitemeza told to vacate office immediately after losing bid to remain Hawks boss.

\section{IIIII}

Phahlane suspended on full pay based on corruption allegations by IPID. He is replaced by Khehla Sitole as National Police Commissioner.

\section{III I I I I}

Supreme Court of Appeals denies Zuma's appeal against Arms Deal charges being reinstated.

\section{1 \\ High Court in Pretoria sets aside} Abrahams' decision to withdraw charges against Jiba. This effectively meant the NPA was obliged to reinstate them.
Mdluli agrees to take early retirement after being suspended with full pay \& benefits for $6 \&$ a half years without any disciplinary action being taken against him regarding his suspension.

Zuma forced to resign \& Ramaphosa takes over as President.

NPA reinstates corruption charges against Zuma.

ConCourt finds removal of Abrahams' predecessor, Nxasana was an abuse of presidential power.

Resulting Abraham's appointment invalid \& that Nxasana must repay the R17m golden handshake.

Ramaphosa appoints Shamila Batohi to NDPP.

Deputy NDPP Jiba \& Mrwebi fired by President Ramaphosa.

Molluli \& a c0-accused convicted on kidnapping \& assault charges.

NPA boss drops racketeering charges against Johan Booysen \& co.

Zuma's legal team abandons

intended appeal to ConCourt for

a permanent stay of prosecution.

Mdluli sentenced to 5 years

\section{imprisonment on assault \&}

kidnapping charges.

Almost 2 decades later Zuma is yet to stand trial re: the Arms Deal. 


\subsection{CONCLUSION}

The Zuma Presidency was therefore associated with a hollowing out of key criminal justice agencies and weakening of their efficacy. Along with unstable and poor-quality senior leadership, the intensification of internal corruption and abuse of resources and numerous irregular promotions the period also saw the loss of competent staff demoralised as a result of the compromising of the institutions for which they worked. The result of this was not only a proliferation of corruption but the overall weakening of the ability of these agencies to tackle crime.

Despite Zuma's claims that government would prioritise the combating of violent crime during his Presidency (ANC, 2009), violent crime worsened during his term of office. After declining during the first three years of his Presidency, the last six years of Zuma's term of office resulted in substantial increases in both murder and armed robbery. During his final year of office, the number of murders (20336) was 31\% greater than during 2011-12 (15554) and overall aggravated robbery had increased by $37 \%$. Most forms of armed robbery increased by larger amounts including car hijacking by $73 \%$, residential robbery by $33 \%$ and non-residential (business) robbery by $38 \%$ (Corruption Watch and Institute for Security Studies, 2019).

Zuma and his Executives meddling with criminal justice agencies had broadly debilitating consequences for South Africa's criminal justice agencies. The collateral damage of Zuma's criminal justice agenda and of state capture was therefore not only an enormous worsening of corruption, but a serious deterioration in the safety of the people of South Africa. 


\section{References}

amaBhungane (2012) 'Friends in high places rescue Mdluli, Mail \& Guardian. [Online]. https://bit.ly/37pUrEa (Accessed 13 December 2019).

ANC (2009) 'Text of the ANC's 2009 election manifesto', Politicsweb. [Online]. https://bit. ly/3s55Xyu (Accessed 13 December 2019).

Bateman, B. (2016) 'McBride: New evidence links Mdluli \& Ntlemeza in plot to oust Dramat', Eyewitness News. [Online]. https://bit. ly/2X2SGe9 (Accessed 13 December 2019).

Breytenbach, G. \& Brodie, N. (2017) Rule of Law. Johannesburg: Pan Macmillan South Africa.

Chabalala, J. (2019) 'Mdluli and his co-accused found guilty of kidnapping and assaulting his former lover's husband', News24. [Online]. https://bit.ly/3fJqZh4 (Accessed 13 December 2019).

Chauke, R. (2019) 'Nomgcobo Jiba gives up on getting job back', Sowetan. [Online]. https://bit.ly/3yybDmY (Accessed 13 December 2019).

City Press (2011a) 'I did not appoint Mdluli'. [Online]. https://bit.ly/37uJbq1 (Accessed 13 December 2019).

City Press (2011b) 'NPA boss backed 'thieving' hubby'. [Online]. https://bit.ly/3f Ixtg0 (Accessed 13 December 2019).

City Press (2012) 'I will quit over Mdluli'. [Online]. https://bit.ly/3xqUAlq (Accessed 21 July 2020).

Constitutional Court of South Africa (2018) Corruption Watch NPC and Others $V$ President of the Republic of South Africa and Others [2018] ZACC 23. [Online]. https:// bit.ly/3xy5h5N (Accessed 5 March 2019).

Corruption Watch and Institute for Security Studies (2019) 'State capture and the political manipulation of criminal justice agencies, Corruption Watch. [Online]. https://bitly/ 3CCJFsP (Accessed 16 September 2019).

Democratic Alliance (2009) 'DA: Statement by Helen Zille, Democratic Alliance leader, on the National Prosecutions Authority (27/11/2009)', Polity.org. [Online]. https://bit.ly/3fGPlb8 (Accessed 13 December 2019).
Department of Safety and Security (2008) 'South African Police Service Act (68/1995): Regulations for the South African Police Service (Gazette No. 31412 - Regulation 973)', Government Gazette. [Online]. https://bit.ly/3xuJ2xC (Accessed 13 December 2019).

Du Toit, P. (2018) 'Deconstructing Gordhan's testimony: Everything you need to know', News24. [Online]. https://bit.ly/3s0VofC (Accessed 15 December 2019).

eNCA (2015a) 'Mdluli case struck off the roll'. [Online]. https://bit.ly/3jCKGIj (Accessed 13 December 2019).

eNCA (2015b) 'Riah Phiyega suspended'. [Online].https://bit.ly/3yyzYsS (Accessed 13 December 2019).

Evans, J. (2015) 'Suspended Gauteng Hawks head officially fired', News24. [Online]. https://bit. ly/3jE6q6T (Accessed 13 December 2019).

Evans, S. (2016) 'Hawks chief 'helped oust' Dramat', Mail \& Guardian. [Online]. https:// bit.ly/2U609Iq (Accessed 13 December 2019).

Eyewitness News (2012) 'Mbalula speaks out on phone tapping'. [Online]. https://bit.ly/ 3Aqir6q (Accessed 13 December 2019).

Gous, N. (2017) 'Mbalula celebrates after last day of acting police boss Mothiba', Times Live. [Online]. https://bit.ly/3CwadeU (Accessed 15 December 2019).

High-Level Review Panel on the SSA (2018) 'High-Level Review Panel Report on the State Security Agency', South African Government. https://bit.ly/3An0DsZ

High Court of South Africa: Kwazulu-Natal (2014) 'Booysen v Acting National Director of Public Prosecutions and Others (4665/2010) [2014]', High Court of South Africa.

High Court of South Africa: Natal Provincial Division (2005) National Director of Public Prosecutions v Schabir Shaik and Others CC 27/04 Durban and Coast Local Division, 31 January 2006 (Squires Judgment). [Online]. https://bit.ly/3xwMLuk (Accessed 12 December 2019). 
High Court of South Africa: Natal Provincial Division (2008) Zuma v National Director of Public Prosecutions (8652/08) [2008] (Nicoleson Judgment). [Online]. https://bit.ly/3iuFgzO

High Court of South Africa: North Gauteng (2016) General Council of the Bar of South Africa v Jiba and Others (23576/2015) [2016].

High Court of South Africa: Witwatersrand Local Division (2006) The State versus Jacob Gedleyihlekisa Zuma. [Online]. https://bit.ly/3AjZKS7 (Accessed 12 December 2019).

Hofstatter, S., Wa Afrika, M. \& Rose, R. (2011) 'Shoot to kill: Inside a South African Police Death Squad', gunsite.co.za. [Online]. https://bit.ly/3s9lDAM (Accessed 13 December 2019).

Holden, P. (2008) The arms deal in your pocket. Jonathan Ball Pub.

Hunter, Q. (2018) 'Harassment 'worse than during apartheid' - Pravin Gordhan', Times Live. [Online]. https://bit.ly/3s3Epct (Accessed 15 December 2019).

Kathree-Setiloane, J. (2013) 'Bheki Cele vs The Sowetan: The judgment', Politicsweb. [Online]. https://bit.ly/2VGqyN9 (Accessed 13 December 2019).

Khumalo, J. (2020) 'Zuma 'hopes his innocence will be demonstrated' as trial resumes', City Press. [Online]. https://bit.ly/3AocgjC (Accessed 21 July 2020).

Lindeque, M. (2014) 'Hawks boss on "precautionary suspension", Eyewitness News. [Online]. https://bit.ly/37sXls0 (Accessed 13 December 2019).

Mahlangu, I. (2018) 'Phiyega denies 'shielding' Mdluli', Sowetan. [Online]. https://bit.ly/ 3xBh6b7 (Accessed 13 December 2019).

Mail \& Guardian (2009) 'Inside operation Destroy Lucifer'. [Online]. https://bit.ly/ 3fJNr9F (Accessed 13 December 2019).

Mail \& Guardian (2017) 'Phahlane out, and yet another new police commissioner in'. [Online]. https://bit.ly/3iBWMCB (Accessed 15 December 2019).
Mashego, A. (2017a) 'Crime intel boss has a dodgy past', City Press. [Online]. https://bit. ly/2VA2yMa (Accessed 13 December 2019).

Mashego, A. (2017b) Crime intelligence gets a new boss, City Press. [Online]. https://bit.ly/ 3IEGBWV (Accessed 13 December 2019).

Mashego, A. (2017c) 'How Nhleko gave Ntlemeza his job', City Press. [Online]. https://bit.ly/2VycrK8 (Accessed 13 December 2019).

Masilela, B. (2016) 'Mdluli in court over 1999 killing', IOL News. [Online] https://bit.ly/ 3xy6mun (Accessed 13 December 2019).

Munusamy, R. (2016) 'Gordhan vs. Ntlemeza: A proxy battle in a war over control of the state, Daily Maverick. [Online]. https://bitly/ 3AoWaGc (Accessed 15 December 2019).

News24 (2016) 'Charges withdrawn against Gordhan and co, [Online] https://bit.ly/ 2U2gayV (Accessed 15 December 2019).

News24 (2018a) 'Former Sunday Times editor Ray Hartley's blistering response to 'death squad' criticism'. https://bit.ly/3s2zys9 (Accessed 21 July 2020).

News24 (2018b) 'Richard Mdluli relieved of all his duties, says Mbalula - As it happened'. [Online]. https://bit.ly/37qdYV9 (Accessed 13 December 2019).

North Gauteng High Court (2013) 'Freedom Under Law v National Director of Public Prosecutions and Others (26912/12) [2013] Judgment 23 September 2013, High Court of South Africa. [Online]. https://bit.ly/3IWU8cH (Accessed 13 December 2019).

Pather, R. (2018) ‘Rewind to 2005: Jacob Zuma has been charged', Mail \& Guardian. [Online]. https://bit.ly/3Cv4WVd (Accessed 21 July 2020).

Pauw, J. (2017) The President's Keepers: Those keeping Zuma in Power and out of Prison. 1st Ed. Cape Town: Tafelberg.

Pitchford, J. (2016) Blood on Their Hands: General Johan Booysen Reveals His Truth. Johannesburg: Pan Macmillan South Africa.

PMG (Parliamentary Monitoring Group) (2016) Withdrawal of charges against Minister of Finance: National Director of Public 
Prosecutions briefing. [Online]. https://bit. ly/3irIBQd (Accessed 15 December 2019).

Raborife, M. (2016) 'State withdraws charges against McBride', News24. [Online]. https://bit.ly/2XckBIV (Accessed 15 December 2019).

Republic of South Africa (1996) Constitution of the Republic of South Africa. Pretoria: Constitutional Assembly.

Roelofse, K.D. (2019) 'Statement and Documents Submitted by Kobus Demeyer Roelofse', Commission of Inquiry into State Capture.

SA News (2009) 'Government and Adv. Vusi Pikoli reach out-of-court settlement'. [Online]. https://bit.ly/3iwIdQx (Accessed 13 December 2019).

SCA (Supreme Court of Appeal of South Africa) (2006) $S_{V}$ Shaik and Others (Criminal Appeal) (62/06) [2006] (6 November 2006). [Online] https://bit.ly/2VB26x9 (Accessed 12 December 2019).

SCA (Supreme Court of Appeal of South Africa) (2009) National Director of Public Prosecutions v Zuma (573/08) [2009] ZASCA 1 (12 Jan 2009). [Online]. https://bit.ly/3iykdN3 (Accessed 12 December 2019).

SCA (Supreme Court of Appeal of South Africa) (2011) Democratic Alliance $v$ The President of the RSA \& others (263/11) [2011] ZASCA 241 (1 December 2011).

SCA (Supreme Court of Appeal of South Africa) (2012) Democratic Alliance v The Acting National Director of Public Prosecutions (288/11) [2012] ZASCA 15 (20 March 2012). [Online]. https://bit.ly/3isYQwm (Accessed 12 December 2019).

SCA (Supreme Court of Appeal of South Africa) (2014a) National Director of Public Prosecutions and Others v Freedom Under Law (67/2014) [2014]. [Online]. https://bit. ly/3xtMHeV (Accessed 13 December 2019).

SCA (Supreme Court of Appeal of South Africa) (2014b) Zuma v DA (836/2013) [2014] ZASCA 101 (28 August 2014). [Online]. https://bit.ly/3Cw2z4a (Accessed 12 December 2019).
SCA (Supreme Court of Appeal of South Africa) (2017) Zuma v DA (771/2016); ANDPP VDA (1170/2016) [2017] ZASCA 146 (13 October 2017). [Online]. https://bit.ly/ 3xxmVXp (Accessed 15 September 2019).

SCA (Supreme Court of Appeal of South Africa) (2018) Jiba \& anotherv The General Council of the Bar of South Africa and Mrwebi $v$ The General Council of the Bar of South Africa (141/17 and 180/17) [2018]. [Online]. https://bit.ly/3xyxnxw (Accessed 13 December 2019).

Siqoko, B. (2018) 'We got it wrong, and for that we apologise', Sunday Times. https://bit.ly/ 3yAcnb7 (Accessed 5 November 2019).

Sole, S. (2015) 'Jiba's secret unit set on Hawks boss', Mail \& Guardian. [Online]. https://bit. ly/37z8VBz (Accessed 13 December 2019).

Sole, S., Brümmer, S. \& Evans, S. (2015) 'Hawks boss Dramat fears for his life', Mail \& Guardian. [Online]. https://bit.ly/3lF4f5H (Accessed 13 December 2019).

Sole, S. \& Evans, S. (2012) 'Zuma bodyguard put in charge of police spy unit', Mail \& Guardian. [Online] https://bit.ly/3s2DI3t (Accessed 13 December 2019).

Sunday Times (2018) 'The death squad that wasn't ...' [Online]. https://bit.ly/2VuKuDg (Accessed 13 December 2019).

Sunday Times Investigation Staff (2011) 'Sent to die - Hawks and SA police arresting suspects and sending them over the border to be murdered', Sunday Times. [Online]. https://bit.ly/3s1Ze8b (Accessed 13 December 2019).

Tandwa, L. (2016) 'Court papers reveal heated exchange between Abrahams, Ntlemeza', News24. [Online]. https://bit.ly/37oZJQq (Accessed 15 December 2019).

Thamm, M. (2016) 'Own Goal: Minister of Police flouted the law, rendering Hawks head a lame duck', Daily Maverick. [Online]. https://bit.ly/3xCVdZm (Accessed 13 December 2019).

Thamm, M. (2017) 'House of Cards: Unfit Ntlemeza a threat and must step down HSF, Daily Maverick. [Online]. https://bit. ly/2VthewI (Accessed 13 December 2019). 
Thamm, M. (2018) 'Shadrack Sibiya has a right to justice against the State Capture enablers still jammed in the system', Daily Maverick. [Online]. https://bitly/3CrcjNl (Accessed 13 December 2019).

The Presidency (2018) President Ramaphosa appoints high-level review panel on State Security Agency. [Online]. https://bit. ly/3CsuuCf (Accessed 13 December 2019).

Underhill, G. (2015) 'Hawks boss: I was 'set up’ to silence corruption investigations', Mail \& Guardian. [Online]. https://bit.ly/3s2DXeT (Accessed 13 December 2019).

Van Wyk, P. (2016) 'Gordhan charges: 'Hawks held back Sars memo", Mail \& Guardian. [Online].https://bit.ly/3s5FhgP (Accessed 15 December 2019).
Wicks, J. (2015) 'Exclusive: Secret report reveals how Panday 'bought' the cops', News 24. [Online].https://bit.ly/3lloLlL (Accessed 13 December 2019).

Zondo Commission (2019a) 'Transcript from Inquiry into State Capture: Day 041 (28-01-2019) - Testimony of Angelo Agrizzi, Commission of Inquiry into State Capture. Johannesburg. [Online]. https://bit.ly/3Asfxlj

Zondo Commission (2019b) 'Transcript from Inquiry into State Capture: Day 173 (30-09-2019) - Testimony of Dhajanaya Naidoo, Commission of Inquiry into State Capture. Johannesburg. [Online]. https://bit.ly/3CsvGWf 


\section{APPENDIX}

\begin{tabular}{|c|c|c|c|c|}
\hline $\begin{array}{l}\text { Case Study } \\
\text { in State } \\
\text { Capture }\end{array}$ & Status & Summary Description & $\begin{array}{l}\text { Investigation } \\
\text { Body / } \\
\text { Source of } \\
\text { Evidence }\end{array}$ & $\begin{array}{l}\text { Government } \\
\text { Entity } \\
\text { Implicated }\end{array}$ \\
\hline \multicolumn{5}{|c|}{ Scandals Connected to Jacob Zuma, Guptas, Other Key Networks and ANC Politics } \\
\hline $\begin{array}{l}\text { The State } \\
\text { of Capture } \\
\text { report- } \\
\text { focuses } \\
\text { on Guptas' } \\
\text { relationship } \\
\text { with Jacob } \\
\text { Zuma and } \\
\text { their alleged } \\
\text { influence on } \\
\text { the affairs } \\
\text { of state }\end{array}$ & $\begin{array}{l}\text { First complaint } \\
\text { was received } \\
\text { in March } 2016 \\
\text { and the report } \\
\text { was released in } \\
\text { November } 2016 .\end{array}$ & $\begin{array}{l}\text { Investigation into complaints of alleged improper } \\
\text { and unethical conduct by the President and } \\
\text { other State Functionaries, relating to alleged } \\
\text { improper relationships and involvement of the } \\
\text { Gupta Family in the removal and appointment } \\
\text { of Ministers and Directors of State-Owned } \\
\text { Enterprises (SOEs), resulting in improper and } \\
\text { possibly corrupt award of State Contracts and } \\
\text { Benefits to the Gupta Family's Businesses. } \\
\text { The report details numerous allegations of } \\
\text { the Guptas' involvement in affairs of the state } \\
\text { and their irregular activities that enable rent } \\
\text { extraction. The findings were not conclusive } \\
\text { and the remedial action was to establish a } \\
\text { commission of inquiry into state capture (to } \\
\text { be appointed by the President, but with a } \\
\text { judge selected by the Chief Justice). Litigation } \\
\text { endeavoured to delay or prohibit the report's } \\
\text { release and implementation of remedial actions, } \\
\text { but failed, and the commission was established } \\
\text { in } 2018 \text {. }\end{array}$ & $\begin{array}{l}\text { - Public } \\
\text { Protector, } \\
\text { followed by } \\
\text { litigation }\end{array}$ & $\begin{array}{l}\text { - GCIS (The } \\
\text { New Age) } \\
\text { - Eskom } \\
\text { (Optimum) } \\
\text { - Transnet } \\
\text { (Regiments/ } \\
\text { Trillian) } \\
\text { - Denel } \\
\text { - SAA (The } \\
\text { New Age) } \\
\text { - SABC (The } \\
\text { New Age) } \\
\text { - Department of } \\
\text { Finance } \\
\text { - Transport } \\
\text { (SAA) } \\
\text { - Communica- } \\
\text { tions (SABC } \\
\text { \& GCIS) }\end{array}$ \\
\hline $\begin{array}{l}\text { Zondo } \\
\text { Commission }\end{array}$ & $\begin{array}{l}\text { Established } \\
\text { in 2018, with } \\
\text { anticipated } \\
\text { conclusion being } \\
\text { the end of } 2021 .\end{array}$ & $\begin{array}{l}\text { Formally titled the Judicial Commission of } \\
\text { Inquiry into Allegations of State Capture, } \\
\text { Corruption and Fraud in the Public Sector } \\
\text { including Organs of State, the Commission } \\
\text { was promulgated by then President Zuma in } \\
\text { response to the remedial actions as outlined in } \\
\text { the Public Protector's State of Capture report. } \\
\text { As of June } 2021 \text {, the Commission that started } \\
\text { in August } 2018 \text { has held more than } 418 \text { days } \\
\text { of hearings of over } 330 \text { testimonies (generating } \\
\text { over } 71000 \text { pages of transcript). The inquiry's } \\
\text { terms of reference were expansive and, as } \\
\text { such, the scope of investigations went beyond } \\
\text { merely looking into the Gupta-related cases, } \\
\text { covering other networks (e.g., Bosasa) as well } \\
\text { as other government institutions (e.g., role } \\
\text { of Parliament). }\end{array}$ & $\begin{array}{l}\text { - Zondo } \\
\text { Commission }\end{array}$ & $\begin{array}{l}\text { Various } \\
\text { work-streams } \\
\text { covering } \\
\text { inter alia: } \\
\text { - SOEs } \\
\text { (Eskom, } \\
\text { Transnet, } \\
\text { Denel, SAA) } \\
\text { - Free State } \\
\quad \text { Provincial } \\
\text { Government } \\
\text { - Bosasa } \\
\text { - SARS } \\
\text { - Law } \\
\text { enforcement } \\
\text { - State Security } \\
\text { Agency (SSA) } \\
\text { - The New Age } \\
\text { \& ANN7 } \\
\text { - Role of } \\
\text { Parliament } \\
\text { and ANC }\end{array}$ \\
\hline
\end{tabular}




\begin{tabular}{|c|c|c|c|c|}
\hline $\begin{array}{l}\text { Case Study } \\
\text { in State } \\
\text { Capture }\end{array}$ & Status & Summary Description & $\begin{array}{l}\text { Investigation } \\
\text { Body / } \\
\text { Source of } \\
\text { Evidence }\end{array}$ & $\begin{array}{l}\text { Government } \\
\text { Entity } \\
\text { Implicated }\end{array}$ \\
\hline \multicolumn{5}{|c|}{ Scandals Connected to Jacob Zuma, Guptas, Other Key Networks and ANC Politics } \\
\hline Bosasa & $\begin{array}{l}\text { Dating back to a } \\
2009 \text { SIU report. } \\
\text { Investigations and } \\
\text { various litigations } \\
\text { are ongoing. }\end{array}$ & $\begin{array}{l}\text { In 2019, former Bosasa C00, Anglo Agrizzi, } \\
\text { testified at the Zondo Commission, detailing } \\
\text { the acts and long history of corruption between } \\
\text { various Bosasa companies predominantly } \\
\text { owned by Gavin Watson, and numerous } \\
\text { government entities/departments. The } \\
\text { testimony of Agrizzi (and other former Bosasa } \\
\text { employees) corroborated the findings of a } \\
2009 \text { SIU investigation that alleged corruption } \\
\text { in several contracts Bosasa had with the } \\
\text { Department of Correctional Services. Criminal } \\
\text { court proceedings have been initiated based } \\
\text { on the } 2009 \text { SIU investigation, along with new } \\
\text { investigations initiated by SARS and other law } \\
\text { enforcement entities. }\end{array}$ & $\begin{array}{l}\text { - Special } \\
\text { Investi- } \\
\text { gation } \\
\text { Unit (SIU) } \\
\text { - Zondo } \\
\text { Commission }\end{array}$ & $\begin{array}{l}\text { - Department of } \\
\text { Correctional } \\
\text { Services } \\
\text { - Department of } \\
\text { Justice } \\
\text { - Department of } \\
\text { Home Affairs } \\
\text { - Department of } \\
\text { Transport } \\
\text { - Various SOEs } \\
\text { (e.g., SAPO, } \\
\text { ACSA) } \\
\text { - National } \\
\text { Prosecuting } \\
\text { Authority } \\
\text { (NPA) } \\
\text { - Members of } \\
\text { Parliament }\end{array}$ \\
\hline Arms Deal & $\begin{array}{l}\text { Various } \\
\text { investigations and } \\
\text { sources, dating } \\
\text { back to 1990s. } \\
\text { Most significant } \\
\text { source being } \\
\text { through Seriti } \\
\text { Commission. } \\
\text { Corruption case } \\
\text { against Zuma is } \\
\text { ongoing. }\end{array}$ & $\begin{array}{l}\text { Commission of Inquiry into allegations of fraud, } \\
\text { corruption, impropriety, or irregularity in the } \\
\text { Strategic Defence Procurement Packages } \\
\text { (SDPP). Various court cases related to } \\
\text { allegations of corruption against Jacob Zuma. } \\
\text { On Monday, } 24 \text { October 2011, the President } \\
\text { announced the Commission chaired by Judge } \\
\text { Seriti. The findings of the Commission were that } \\
\text { there was "no evidence" of corruption, but this } \\
\text { is seen by many to have been a whitewash. The } \\
\text { report was taken on review and set aside in } \\
\text { August } 2019 \text {. The corruption case against Zuma } \\
\text { is ongoing before the courts. }\end{array}$ & $\begin{array}{l}\text { - Seriti } \\
\text { Commission } \\
\text { - Various } \\
\text { court cases }\end{array}$ & $\begin{array}{l}\text { Initially: } \\
\text { - South African } \\
\text { National } \\
\text { Defence } \\
\text { Force } \\
\text { - Members of } \\
\text { Parliament } \\
\text { Allegations also } \\
\text { involve: } \\
\text { - NPA } \\
\text { - SSA }\end{array}$ \\
\hline $\begin{array}{l}\text { Nkandla } \\
\text { Security } \\
\text { Upgrades }\end{array}$ & $\begin{array}{l}\text { Investigation } \\
\text { started in } \\
\text { November } 2012 . \\
\text { Report on } \\
\text { investigation } \\
\text { was released in } \\
\text { March } 2014 .\end{array}$ & $\begin{array}{l}\text { Report on security upgrades to President } \\
\text { Zuma's homestead in Nkandla. The investigation } \\
\text { found that the President unduly benefited from } \\
\text { the upgrades and as part of remedial actions } \\
\text { the President was required to pay back a portion } \\
\text { of the costs of the upgrades. Zuma instructed } \\
\text { that SAPS undertake their own investigation, } \\
\text { which sought to rationalise the expenses (fire- } \\
\text { pool report). Parliament accepted this alternative } \\
\text { report, but major court cases followed, } \\
\text { ultimately declaring that the Public Protector's } \\
\text { remedial actions are binding. President and } \\
\text { Parliament failed to uphold the Constitution. } \\
\text { President ordered to "pay back the money". }\end{array}$ & $\begin{array}{l}\text { - Public } \\
\text { Protector's } \\
\text { Secured } \\
\text { in Comfort } \\
\text { report, } \\
\text { followed by } \\
\text { litigation }\end{array}$ & $\begin{array}{l}\text { - } \text { Department of } \\
\text { Public Works } \\
\text { - South African } \\
\text { Police Service }\end{array}$ \\
\hline
\end{tabular}




\begin{tabular}{|c|c|c|c|c|}
\hline $\begin{array}{l}\text { Case Study } \\
\text { in State } \\
\text { Capture }\end{array}$ & Status & Summary Description & $\begin{array}{l}\text { Investigation } \\
\text { Body / } \\
\text { Source of } \\
\text { Evidence }\end{array}$ & $\begin{array}{l}\text { Government } \\
\text { Entity } \\
\text { Implicated }\end{array}$ \\
\hline \multicolumn{5}{|c|}{ Scandals Connected to Jacob Zuma, Guptas, Other Key Networks and ANC Politics } \\
\hline $\begin{array}{l}\text { Private } \\
\text { Aircraft } \\
\text { Landing at } \\
\text { Waterkloof } \\
\text { Airforce Base } \\
\text { and Gupta } \\
\text { Sun City } \\
\text { Wedding }\end{array}$ & May 2013. & $\begin{array}{l}\text { In 2013, justice, crime prevention, and } \\
\text { security cluster (JCPS) - a cabinet structure } \\
\text { composed of various ministries - undertook an } \\
\text { investigation into the Landing of a Commercial } \\
\text { aircraft at Air Force Base Waterkloof (report } \\
\text { titled the same). The investigation revealed that } \\
\text { the Guptas initially tried to organise a special } \\
\text { landing at OR Tambo International Airport, but } \\
\text { was turned down. They then approached the } \\
\text { Indian High Commission who re-designated the } \\
\text { wedding entourage as an official delegation to } \\
\text { secure a landing at the Waterkloof base. The } \\
\text { wedding held at Sun City was attended by a } \\
\text { number of high-profile ANC politicians and was } \\
\text { paid for in part by moneys looted from the Vrede } \\
\text { Dairy Farm project. }\end{array}$ & $\begin{array}{l}\text { - Report by } \\
\text { JPCS } \\
\text { - Zondo } \\
\text { Commission } \\
\end{array}$ & \begin{tabular}{|l} 
- Department of \\
International \\
Relations and \\
Cooperation \\
(DIRCO) \\
- Department of \\
Defence \\
- Department of \\
Transport
\end{tabular} \\
\hline $\begin{array}{l}\text { Free State } \\
\text { Provincial } \\
\text { Capture, } \\
\text { includes } \\
\text { Vrede Dairy } \\
\text { Farm and } \\
\text { Asbestos } \\
\text { Contracts }\end{array}$ & Ongoing. & $\begin{array}{l}\text { The Vrede Dairy Farm project was initiated } \\
\text { by the Free State Provincial Government as a } \\
\text { development project, however, in partnering with } \\
\text { a Gupta-linked company Estina, government } \\
\text { funds were looted. In 2018, the Public } \\
\text { Protector released a report on their } 2018 \\
\text { investigation, but it was taken on review and } \\
\text { set aside by the courts. The second part of the } \\
\text { investigation is yet to be finalised. The NPA } \\
\text { laid criminal charges against Gupta associates } \\
\text { and implicated government officials. Court } \\
\text { proceedings are ongoing. } \\
\text { Significant testimony and evidence have been } \\
\text { presented at the Zondo Commission regarding } \\
\text { the Vrede Farm case, as well as the asbestos } \\
\text { inspection project (criminal proceedings are also } \\
\text { underway). Both projects implicate high-profile } \\
\text { politicians and senior officials manipulating } \\
\text { government process. }\end{array}$ & $\begin{array}{l}\text { - Public } \\
\text { Protector } \\
\text { reports } \\
\text { - Zondo } \\
\text { Commission } \\
\text { - Various } \\
\text { court cases } \\
\end{array}$ & $\begin{array}{l}\text { - Free State } \\
\text { Provincial } \\
\text { Government }\end{array}$ \\
\hline $\begin{array}{l}\text { Irregular } \\
\text { removal of } \\
\text { National } \\
\text { Director } \\
\text { of Public } \\
\text { Prosecutions } \\
\text { (NDPP), } \\
\text { Mxolisi } \\
\text { Nxasana }\end{array}$ & $\begin{array}{l}\text { Inquiry instituted } \\
\text { in February } 2015, \\
\text { but was cancelled } \\
\text { in May } 2015 . \\
\text { This triggers the } \\
\text { Constitutional Court } \\
\text { cases that followed. }\end{array}$ & $\begin{array}{l}\text { Inquiry into the fitness of Mxolisi Nxasana to } \\
\text { hold office as NDPP. The Inquiry was cancelled } \\
\text { after Zuma "agreed to let Nxasana resign". He } \\
\text { was paid R17m - the balance of his ten-year } \\
\text { contract. Court cases followed detailing the } \\
\text { abuse of the presidency powers by Zuma. } \\
\text { Ultimately, Nxasana was ordered to repay } \\
\text { R17m and Zuma's appointed replacement, } \\
\text { Shawn Abrahams, was ordered to vacate office. } \\
\text { Constitutional Court found Zuma's actions to } \\
\text { be an abuse of power and in breach of his } \\
\text { constitutional obligations. }\end{array}$ & $\begin{array}{l}\text { - Cassim } \\
\text { Inquiry into } \\
\text { fitness of } \\
\text { Mxolisi } \\
\text { Nxasana to } \\
\text { hold office } \\
\text { of NDPP } \\
\text { initiated } \\
\text { by Zuma, } \\
\text { followed by } \\
\text { litigation }\end{array}$ & $\begin{array}{l}\text { - National } \\
\text { Prosecution } \\
\text { Authority }\end{array}$ \\
\hline $\begin{array}{l}\text { Political } \\
\text { killings in } \\
\text { KZN }\end{array}$ & $\begin{array}{l}\text { Established in } \\
\text { October } 2016 . \text { The } \\
\text { report was released } \\
\text { in May } 2018 .\end{array}$ & $\begin{array}{l}\text { On } 28 \text { October 2016, the Premier of the } \\
\text { Province of KwaZulu-Natal established a } \\
\text { Commission of Enquiry into the Underlying } \\
\text { Causes of the Murder of Politicians in KwaZulu- } \\
\text { Natal (KZN). }\end{array}$ & $\begin{array}{l}\text { - Moerane } \\
\text { Commission } \\
\text { of Enquiry }\end{array}$ & $\begin{array}{l}\text { - KZN Provincial } \\
\text { Government } \\
\text { - KZN Local } \\
\text { Governments }\end{array}$ \\
\hline
\end{tabular}




\begin{tabular}{|c|c|c|c|c|}
\hline $\begin{array}{l}\text { Case Study } \\
\text { in State } \\
\text { Capture }\end{array}$ & Status & Summary Description & $\begin{array}{l}\text { Investigation } \\
\text { Body / } \\
\text { Source of } \\
\text { Evidence }\end{array}$ & $\begin{array}{l}\text { Government } \\
\text { Entity } \\
\text { Implicated }\end{array}$ \\
\hline \multicolumn{5}{|c|}{ Scandals Connected to Jacob Zuma, Guptas, Other Key Networks and ANC Politics } \\
\hline \multicolumn{5}{|c|}{ State Capture of State-Owned Enterprises and Government Departments } \\
\hline $\begin{array}{l}\text { Interference } \\
\text { in operations } \\
\text { at the SABC }\end{array}$ & $\begin{array}{l}\text { The Ad Hoc } \\
\text { Committee was } \\
\text { established in } \\
\text { November } 2016 \\
\text { and final report } \\
\text { was tabled on } \\
24 \text { February } 2017 .\end{array}$ & $\begin{array}{l}\text { Parliamentary Ad Hoc Committee on the } \\
\text { SABC Board Inquiry into mismanagement and } \\
\text { interference in SABC operations. Findings } \\
\text { include evidence of Minister Faith Muthambi's } \\
\text { interference in the organisation and editorial } \\
\text { interference, in the firing of SABC } 8 \text { who } \\
\text { protested censorship of the national broadcaster } \\
\text { (on instruction from COO Hlaudi Motsoeneng). It } \\
\text { should be noted that the inquiry was preceded } \\
\text { by an investigation by the Public Protector. } \\
\text { Details are contained in the } 2014 \text { report titled } \\
\text { When Governance and Ethics Fail. }\end{array}$ & $\begin{array}{l}\text { - Parliamen- } \\
\text { tary Inquiry } \\
\text { - Preceded by } \\
\text { an investi- } \\
\text { gation by } \\
\text { the Public } \\
\text { Protector }\end{array}$ & $\begin{array}{l}\text { - SABC } \\
\text { (Department } \\
\text { of Communi- } \\
\text { cation) }\end{array}$ \\
\hline \multirow[t]{2}{*}{$\begin{array}{l}\text { Passenger } \\
\text { Rail Agency } \\
\text { of South } \\
\text { Africa } \\
\text { (PRASA) }\end{array}$} & $\begin{array}{l}\text { Complaints were } \\
\text { lodged in } 2012 \\
\text { and the report } \\
\text { was released in } \\
\text { August } 2015 \text {. }\end{array}$ & $\begin{array}{l}\text { Several cases of "mismanagement and } \\
\text { irregularities" regarding various contracts. } \\
\text { Lucky Montana was CEO at the time. One of } \\
\text { the remedial actions stipulated that National } \\
\text { Treasury was to investigate all PRASA contracts } \\
\text { from } 2012 \text { onwards with a value of R10 million } \\
\text { or more. National Treasury implemented the } \\
\text { remedial action which resulted in several } \\
\text { investigations, the details of which were leaked } \\
\text { to the public. }\end{array}$ & $\begin{array}{l}\text { - Public } \\
\text { Protector's } \\
\text { Derailed } \\
\text { report on } \\
\text { PRASA } \\
\text { - Numerous } \\
\text { investiga- } \\
\text { tions }\end{array}$ & $\begin{array}{l}\text { - PRASA } \\
\text { - Department of } \\
\text { Transport }\end{array}$ \\
\hline & $\begin{array}{l}\text { In June } 2017, \\
\text { Parliament directed } \\
4 \text { committees to } \\
\text { investigate state } \\
\text { capture. Committee } \\
\text { hearings were not } \\
\text { completed. }\end{array}$ & $\begin{array}{l}\text { In terms of the parliamentary directive, the } \\
\text { Portfolio Committee on Transport was requested } \\
\text { to establish an Inquiry into State Capture at } \\
\text { PRASA. However, the Portfolio Committee noted } \\
\text { that PRASA was not mentioned in the Public } \\
\text { Protector's State of Capture report and decided } \\
\text { they would focus on the various investigation } \\
\text { reports produced for National Treasury (as } \\
\text { recommended in Derailed report). }\end{array}$ & $\begin{array}{l}\text { - Portfolio } \\
\text { Committee } \\
\text { on Transport }\end{array}$ & $\begin{array}{l}\text { - PRASA } \\
\text { - Department of } \\
\text { Transport }\end{array}$ \\
\hline $\begin{array}{l}\text { Eskom } \\
\text { Inquiry into } \\
\text { State Capture }\end{array}$ & $\begin{array}{l}\text { In June } 2017 \text {, } \\
\text { Parliament directed } \\
4 \text { committees } \\
\text { to investigate } \\
\text { state capture. } \\
\text { Public Enterprises } \\
\text { Committee } \\
\text { report on Eskom } \\
\text { was released in } \\
\text { November } 2018 .\end{array}$ & $\begin{array}{l}\text { Extensive hearings were held by the Committee } \\
\text { detailing much of the evidence presented in } \\
\text { the Public Protector's report. The Committee } \\
\text { presented recommendations and compiled } \\
\text { a final report detailing their findings. These } \\
\text { included findings that Ministers Lynne Brown } \\
\text { and Malusi Gigaba were negligent and had to } \\
\text { be held accountable. Also recommended that } \\
\text { criminal investigations be undertaken against } \\
\text { the relevant Eskom executives. }\end{array}$ & $\begin{array}{l}\text { - Parliamen- } \\
\text { tary Inquiry }\end{array}$ & $\begin{array}{l}\text { - Eskom } \\
\text { - Department } \\
\text { of Public } \\
\text { Enterprises }\end{array}$ \\
\hline $\begin{array}{l}\text { Nugent } \\
\text { Commission } \\
\text { - SARS } \\
\text { Inquiry }\end{array}$ & $\begin{array}{l}\text { The Inquiry was } \\
\text { constituted on } \\
24 \text { May } 2018 \text { and } \\
\text { the final report } \\
\text { was released in } \\
\text { December } 2018 \text {. }\end{array}$ & $\begin{array}{l}\text { Commission of Inquiry into tax administration } \\
\text { and governance by South African Revenue } \\
\text { Service (SARS). Tom Moyane was fired based on } \\
\text { the interim report released in September } 2018 . \\
\text { The inquiry found that Moyane, with the help of } \\
\text { consultancy company Bain, had implemented } \\
\text { restructuring of the organisation, resulting in } \\
\text { gross mismanagement and erosion of SARS. } \\
\text { Moyane motivated the restructuring based on } \\
\text { the "rogue unit" narrative that has been the } \\
\text { subject of several other debunked investigations } \\
\text { and the subject of much litigation. }\end{array}$ & $\begin{array}{l}\text { - Judicial } \\
\text { Commission } \\
\text { of Inquiry } \\
\text { - Court cases } \\
\text { around the } \\
\text { "rogue unit" } \\
\text { narrative }\end{array}$ & $\begin{array}{l}\text { - SARS } \\
\text { (National } \\
\text { Treasury) }\end{array}$ \\
\hline
\end{tabular}




\begin{tabular}{|c|c|c|c|c|}
\hline $\begin{array}{l}\text { Case Study } \\
\text { in State } \\
\text { Capture }\end{array}$ & Status & Summary Description & $\begin{array}{l}\text { Investigation } \\
\text { Body / } \\
\text { Source of } \\
\text { Evidence }\end{array}$ & $\begin{array}{l}\text { Government } \\
\text { Entity } \\
\text { Implicated }\end{array}$ \\
\hline \multicolumn{5}{|c|}{ Scandals Connected to Jacob Zuma, Guptas, Other Key Networks and ANC Politics } \\
\hline \multicolumn{5}{|c|}{ State Capture of State-Owned Enterprises and Government Departments } \\
\hline $\begin{array}{l}\text { Commission } \\
\text { of Inquiry } \\
\text { into Public } \\
\text { Investment } \\
\text { Corporation } \\
\text { (PIC) }\end{array}$ & $\begin{array}{l}\text { In October } 2018 \text {, } \\
\text { the Commission } \\
\text { was constituted, } \\
\text { and the final report } \\
\text { was released in } \\
\text { March } 2020 .\end{array}$ & $\begin{array}{l}\text { Commission of Inquiry into allegations of } \\
\text { impropriety regarding Public Investment } \\
\text { Corporation (PIC). There were extensive hearings } \\
\text { on various 'dodgy' deals the PIC entered } \\
\text { into and details of political and executive } \\
\text { interference in the operations and decision- } \\
\text { making processes of the investment agency. }\end{array}$ & $\begin{array}{l}\text { - Judicial } \\
\text { Commission } \\
\text { of Inquiry }\end{array}$ & $\begin{array}{l}\text { - PIC (National } \\
\text { Treasury) }\end{array}$ \\
\hline $\begin{array}{l}\text { South African } \\
\text { Social } \\
\text { Security } \\
\text { Agency } \\
\text { (SASSA) }\end{array}$ & $\begin{array}{l}\text { Various } \\
\text { Constitutional Court } \\
\text { cases from } 2011 \\
\text { to } 2018 \text { resulted } \\
\text { in removal of CPS } \\
\text { as service provider } \\
\text { to SASSA. }\end{array}$ & $\begin{array}{l}\text { In 2014, South African Social Security Agency's } \\
\text { (SASSA) } 2012 \text { contract with CPS was found } \\
\text { to be irregular and invalid, however, due to the } \\
\text { importance of ensuring beneficiaries received } \\
\text { grants, CPS continued to be the service } \\
\text { providers until } 2018 \text {. Following a March } 2017 \\
\text { ruling, the Constitutional Court instituted a } \\
\text { Section } 38 \text { Inquiry into Minister Bathabile } \\
\text { Dlamini's personal liability for the narrowly } \\
\text { averted grant payment crisis. }\end{array}$ & $\begin{array}{l}\text { Primary } \\
\text { sources: } \\
\text { - AllPay court } \\
\text { case } \\
\text { - Black Sash } \\
\text { court case }\end{array}$ & - SASSA \\
\hline $\begin{array}{l}\text { South African } \\
\text { Airways (SAA) } \\
\text { and SAA } \\
\text { Technical }\end{array}$ & $\begin{array}{l}\text { Court case } \\
\text { to have Dudu } \\
\text { Myeni declared a } \\
\text { delinquent director } \\
\text { was launched } \\
\text { in } 2017 .\end{array}$ & $\begin{array}{l}\text { Court case was launched in } 2017 \text { by Outa and } \\
\text { the SAA Pilots' Association (SAAPA) to declare } \\
\text { Myeni a delinquent director in terms of the } \\
\text { Companies Act, based on her actions while she } \\
\text { was chairperson of the SAA Board. In 2020, the } \\
\text { High Court declared Myeni a delinquent director } \\
\text { for life. A significant amount of new evidence } \\
\text { also emerged through the Zondo Commission, } \\
\text { outlining how the operations at SAA were } \\
\text { undermined and how Myeni and others abused } \\
\text { their positions of authority. }\end{array}$ & $\begin{array}{l}\text { - Court } \\
\text { papers } \\
\text { - Zondo } \\
\text { Commission }\end{array}$ & $\begin{array}{l}\text { - SAA } \\
\text { - SAA Technical }\end{array}$ \\
\hline $\begin{array}{l}\text { Gupta Family } \\
\text { Naturalisation }\end{array}$ & $\begin{array}{l}\text { In June } 2017, \\
\text { Parliament directed } \\
4 \text { committees to } \\
\text { investigate state } \\
\text { capture. Final } \\
\text { report was tabled } \\
14 \text { March } 2019 .\end{array}$ & $\begin{array}{l}\text { Portfolio Committee on Home Affairs Inquiry into } \\
\text { the Gupta Family Naturalisation was established } \\
\text { in terms of the Parliamentary directive. Hearings } \\
\text { formally started on } 12 \text { September 2018. Final } \\
\text { report was tabled on } 14 \text { March 2019. Questions } \\
\text { were raised around contracts with Visa } \\
\text { Facilitation Services. This matter is ongoing as } \\
\text { of December } 2020 \text {. }\end{array}$ & $\begin{array}{l}\text { - Portfolio } \\
\text { Committee } \\
\text { on Home } \\
\text { Affairs }\end{array}$ & $\begin{array}{l}\text { - Department of } \\
\text { Home Affairs }\end{array}$ \\
\hline $\begin{array}{l}\text { Inquiry into } \\
\text { State Capture } \\
\text { related to } \\
\text { Gupta-owned } \\
\text { mines }\end{array}$ & $\begin{array}{l}\text { In June } 2017, \\
\text { Parliament directed } \\
4 \text { committees } \\
\text { to investigate } \\
\text { state capture. }\end{array}$ & $\begin{array}{l}\text { Though the Committee drafted a term of } \\
\text { reference for the Inquiry, the activities of holding } \\
\text { hearings and consolidating the evidence never } \\
\text { materialised beyond questions being put to then } \\
\text { Minister Zwane. }\end{array}$ & $\begin{array}{l}\text { - Portfolio } \\
\text { Committee } \\
\text { on Mineral } \\
\text { Resources }\end{array}$ & $\begin{array}{l}\text { - Department } \\
\text { of Mineral } \\
\text { Resources }\end{array}$ \\
\hline
\end{tabular}




\begin{tabular}{|c|c|c|c|c|}
\hline $\begin{array}{l}\text { Case Study } \\
\text { in State } \\
\text { Capture }\end{array}$ & Status & Summary Description & $\begin{array}{l}\text { Investigation } \\
\text { Body / } \\
\text { Source of } \\
\text { Evidence }\end{array}$ & $\begin{array}{l}\text { Government } \\
\text { Entity } \\
\text { Implicated }\end{array}$ \\
\hline \multicolumn{5}{|c|}{ Scandals Connected to Jacob Zuma, Guptas, Other Key Networks and ANC Politics } \\
\hline \multicolumn{5}{|c|}{ State Capture of State-Owned Enterprises and Government Departments } \\
\hline \multirow{3}{*}{$\begin{array}{l}\text { Various } \\
\text { investigations } \\
\text { relating to } \\
\text { State Capture } \\
\text { at Eskom }\end{array}$} & 2015 & $\begin{array}{l}\text { In 2015, Dentons produced an interim report } \\
\text { on their investigations into Status of Business } \\
\text { and Challenges at Eskom. Their investigation } \\
\text { was halted. }\end{array}$ & - Eskom & - Eskom \\
\hline & \multirow[t]{2}{*}{2017} & $\begin{array}{l}\text { In 2017, PricewaterhouseCoopers (PwC) was } \\
\text { appointed by National Treasury to investigate } \\
\text { Eskom's Coal Procurement Processes. Damning } \\
\text { findings were made in relation to Gupta-owned } \\
\text { Tegeta mine contracts and poor coal quality. }\end{array}$ & - Eskom & - Eskom \\
\hline & & $\begin{array}{l}\text { G9 was contracted by Eskom to investigate } \\
\text { the Trillian/McKinsey contracts. Interim report } \\
\text { presented to Board of Eskom in August } 2017 . \\
\text { The investigation remained incomplete, and } \\
\text { no report is available in the public domain. } \\
\text { Evidence from the investigation was presented } \\
\text { in the Parliamentary Inquiry into Eskom } \\
\text { State Capture. }\end{array}$ & $\begin{array}{l}\text { - National } \\
\text { Treasury }\end{array}$ & - Eskom \\
\hline $\begin{array}{l}\text { National } \\
\text { Treasury } \\
\text { Fundudzi } \\
\text { reports, } \\
\text { related to } \\
\text { Eskom and } \\
\text { Transnet }(x 3)\end{array}$ & $\begin{array}{l}\text { Final reports } \\
\text { compiled in } \\
\text { November } 2018 \\
\text { and released to } \\
\text { the public shortly } \\
\text { thereafter. }\end{array}$ & $\begin{array}{l}\text { Investigations requested by National Treasury } \\
\text { of alleged corruption at Transnet and Eskom. } \\
\text { The three reports focused on Eskom (general), } \\
\text { the contracts related to Trillian/McKinsey and } \\
\text { Transnet Locomotives. }\end{array}$ & $\begin{array}{l}\text { - National } \\
\text { Treasury } \\
\text { Fundudzi }\end{array}$ & $\begin{array}{l}\text { - Eskom } \\
\text { - Transnet }\end{array}$ \\
\hline \multirow[t]{2}{*}{$\begin{array}{l}\text { Transnet } \\
\text { Locomotive } \\
\text { Contracts }\end{array}$} & \multirow[t]{2}{*}{$\begin{array}{l}\text { Investigations } \\
\text { commenced in } \\
\text { December } 2017 \\
\text { and reports on } \\
\text { findings submitted } \\
\text { during } 2018 .\end{array}$} & $\begin{array}{l}\text { Werksmans Attorneys was appointed in } \\
\text { December } 2017 \text { to undertake an investigation } \\
\text { into the } 1064 \text { Transnet Locomotives } \\
\text { procurement process, however, the investigation } \\
\text { was halted. No report in the public domain. }\end{array}$ & - Werksmans & - Transnet \\
\hline & & $\begin{array}{l}\text { Mncedisi Ndlovu \& Sedumedi (MNS) Attorneys } \\
\text { was then appointed to investigate } 1064 \\
\text { locomotives procurement process. The report } \\
\text { is not in the public domain, but media indicates } \\
\text { that recommendations mirror the Werksmans' } \\
\text { findings and recommends that Molefe face } \\
\text { criminal charges. }\end{array}$ & $\begin{array}{l}\text { - Mncedisi } \\
\text { Ndlovu \& } \\
\text { Sedumedi }\end{array}$ & - Transnet \\
\hline $\begin{array}{l}\text { Inquiry into } \\
\text { State Capture } \\
\text { at Transnet } \\
\text { and Denel }\end{array}$ & $\begin{array}{l}\text { In June } 2017, \\
\text { Parliament directed } \\
4 \text { committees to } \\
\text { investigate state } \\
\text { capture. Committee } \\
\text { hearings were not } \\
\text { completed. }\end{array}$ & $\begin{array}{l}\text { A detailed information booklet was prepared } \\
\text { in relation to Transnet, however, hearings were } \\
\text { not held before the end of term of Parliament. } \\
\text { Following National elections in } 2019 \text {, it } \\
\text { was decided that outstanding Inquiries into } \\
\text { state capture be postponed indefinitely until } \\
\text { conclusion of the Zondo Commission. }\end{array}$ & $\begin{array}{l}\text { - Portfolio } \\
\text { Committee } \\
\text { on Public } \\
\text { Enterprises }\end{array}$ & $\begin{array}{l}\text { - Transnet } \\
\text { - Denel }\end{array}$ \\
\hline
\end{tabular}




\begin{tabular}{|c|c|c|c|c|}
\hline $\begin{array}{l}\text { Case Study } \\
\text { in State } \\
\text { Capture }\end{array}$ & Status & Summary Description & $\begin{array}{l}\text { Investigation } \\
\text { Body / } \\
\text { Source of } \\
\text { Evidence }\end{array}$ & $\begin{array}{l}\text { Government } \\
\text { Entity } \\
\text { Implicated }\end{array}$ \\
\hline \multicolumn{5}{|c|}{ Scandals Connected to Jacob Zuma, Guptas, Other Key Networks and ANC Politics } \\
\hline \multicolumn{5}{|c|}{ Law Enforcement and the Security Cluster } \\
\hline $\begin{array}{l}\text { Enquiry into } \\
\text { Jiba and } \\
\text { Mrwebi's } \\
\text { fitness to } \\
\text { hold office } \\
\text { at NPA }\end{array}$ & $\begin{array}{l}\text { Established in } \\
\text { November } 2018 . \\
\text { Report was issued } \\
\text { in April } 2019 .\end{array}$ & $\begin{array}{l}\text { Presidential Enquiry into the fitness to hold } \\
\text { office of suspended NPA senior advocates } \\
\text { Nomgcobo Jiba and Lawrence Mrwebi. NPA's } \\
\text { deputy head Jiba, and Mrwebi, the head of } \\
\text { the Specialised Commercial Crimes Unit, were } \\
\text { suspended in October } 2018 \text { by President Cyril } \\
\text { Ramaphosa. The Inquiry was headed by retired } \\
\text { Constitutional Court Justice Yvonne Mokgoro. } \\
\text { Jiba and Mrwebi were accused of improper } \\
\text { conduct in their handling of cases involving } \\
\text { former crime intelligence head Richard Mdluli, } \\
\text { as well as former KwaZulu-Natal Hawks boss } \\
\text { Johan Booysen. }\end{array}$ & $\begin{array}{c}\text { - Mokgoro } \\
\text { Enquiry }\end{array}$ & $\begin{array}{l}\text { - } \text { National } \\
\text { Prosecuting } \\
\text { Authority }\end{array}$ \\
\hline $\begin{array}{l}\text { High-Level } \\
\text { Review Panel } \\
\text { on the State } \\
\text { Security } \\
\text { Agency (SSA) }\end{array}$ & $\begin{array}{l}\text { Established in June } \\
2018 \text { and final } \\
\text { report was sent to } \\
\text { the President in } \\
\text { December } 2018 .\end{array}$ & $\begin{array}{l}\text { The High-Level Review Panel into the SSA } \\
\text { was established by President Ramaphosa in } \\
\text { June 2018. The key finding was a serious } \\
\text { politicisation and factionalisation of the } \\
\text { intelligence community over the past decade } \\
\text { or more. This resulted in "an almost complete } \\
\text { disregard for the Constitution, policy, legislation } \\
\text { and other prescripts, and [turned] our civilian } \\
\text { intelligence community into a private resource } \\
\text { to serve the political and personal interests of } \\
\text { particular individuals" (High-Level Review Panel } \\
\text { on the SSA, 2018, p. ii). }\end{array}$ & $\begin{array}{l}\text { - Review } \\
\text { Panel } \\
\text { established } \\
\text { by President } \\
\text { Ramaphosa }\end{array}$ & - SSA \\
\hline $\begin{array}{l}\text { Various court } \\
\text { cases against } \\
\text { persons } \\
\text { within law } \\
\text { enforcement }\end{array}$ & Ongoing. & $\begin{array}{l}\text { Though testimony and evidence have been } \\
\text { presented at the Zondo Commission, it is } \\
\text { understood that no definitive findings will be } \\
\text { made regarding the capture of law enforcement } \\
\text { under the Zuma administration. Since } 2012 \\
\text { onwards, there were several court cases } \\
\text { that were pursued against individuals in law } \\
\text { enforcement, all of which have been either } \\
\text { dismissed or withdrawn. Most noteworthy are } \\
\text { the cases involved, amongst others: Anwa } \\
\text { Dramat and Shadrack Sibiya of the Hawks } \\
\text { (and Robert McBride from Independent Police } \\
\text { Investigative Directorate [IPID]) for allegations } \\
\text { related to the "Zimbabwean rendition" matter; } \\
\text { Johan Booysen for alleged racketeering as part } \\
\text { of "Cato Manor hit squad"; and the various } \\
\text { senior officials accused of being part of the } \\
\text { "rogue" intelligence unit at SARS. Other court } \\
\text { cases that have provided significant evidence } \\
\text { indicating the capture of law enforcement relate } \\
\text { to the irregular appointed allies of the Shadow } \\
\text { State capture network or the irrational removal } \\
\text { of potential opponents holding senior positions } \\
\text { in law enforcement. Example is the irregular } \\
\text { removal of Mxolisi Nxasana as National Director } \\
\text { of Public Prosecutions (NDPP). }\end{array}$ & $\begin{array}{l}\text { - Various } \\
\text { court cases, } \\
\text { proceedings } \\
\text { in Parlia- } \\
\text { ment } \\
\text { - Zondo } \\
\text { Commission }\end{array}$ & $\begin{array}{l}\text { - NPA } \\
\text { - SAPS } \\
\text { - Hawks } \\
\text { - IPID }\end{array}$ \\
\hline
\end{tabular}




\begin{tabular}{|c|c|c|c|c|}
\hline $\begin{array}{l}\text { Case Study } \\
\text { in State } \\
\text { Capture }\end{array}$ & Status & Summary Description & $\begin{array}{l}\text { Investigation } \\
\text { Body / } \\
\text { Source of } \\
\text { Evidence }\end{array}$ & $\begin{array}{l}\text { Government } \\
\text { Entity } \\
\text { Implicated }\end{array}$ \\
\hline \multicolumn{5}{|c|}{ Scandals Connected to Jacob Zuma, Guptas, Other Key Networks and ANC Politics } \\
\hline \multicolumn{5}{|c|}{ Investigations concerning Private Sector } \\
\hline $\begin{array}{l}\text { Budlender } \\
\text { report on } \\
\text { Trillian }\end{array}$ & $\begin{array}{l}\text { Released in } \\
\text { June } 2017 .\end{array}$ & $\begin{array}{l}\text { Trillian Holdings Board appointed Geoff } \\
\text { Budlender SC to undertake investigations into } \\
\text { State Capture allegations at Trillian Capital. } \\
\text { Detailed accounts from whistle-blowers } \\
\text { highlighted how information was withheld by } \\
\text { senior management at Trillian. }\end{array}$ & - Trillion & - Eskom \\
\hline $\begin{array}{l}\text { Collapse of } \\
\text { VBS Mutual } \\
\text { Bank }\end{array}$ & $\begin{array}{l}\text { Investigation } \\
\text { launched in } \\
\text { April } 2018 \text { and } \\
\text { the report was } \\
\text { released in } \\
\text { October } 2018 .\end{array}$ & $\begin{array}{l}\text { Minister of Finance placed VBS under } \\
\text { curatorship with effect from } 11 \text { March 2018. In } \\
\text { April 2018, the Deputy Governor of the South } \\
\text { African Reserve Bank instituted an investigation } \\
\text { into VBS. The outcomes of the investigation } \\
\text { showed blatant fraud and corruption by senior } \\
\text { executives/Board and how they extracted } \\
\text { money from the bank. Municipal funds were } \\
\text { illegally deposited with VBS (senior ANC and } \\
\text { EFF politicians have been implicated). }\end{array}$ & $\begin{array}{l}\text { - SARB } \\
\text { investiga- } \\
\text { tion report } \\
\text { VBS Mutual } \\
\text { Bank - The } \\
\text { Great Bank } \\
\text { Heist }\end{array}$ & $\begin{array}{l}\text { - Several } \\
\text { Provincial and } \\
\text { Municipal } \\
\text { Officials } \\
\text { (Limpopo } \\
\text { Government) } \\
\text { - SOEs } \\
\text { (particularly } \\
\text { PRASA) }\end{array}$ \\
\hline $\begin{array}{l}\text { SA Institute } \\
\text { of Chartered } \\
\text { Accountants' } \\
\text { (SAICA) } \\
\text { investigation } \\
\text { into KPMG }\end{array}$ & $\begin{array}{l}\text { Final report was } \\
\text { handed to SAICA in } \\
\text { December } 2018 .\end{array}$ & $\begin{array}{l}\text { SA Institute of Chartered Accountants (SAICA) } \\
\text { established an Inquiry to investigate state } \\
\text { capture related allegations of misconduct of its } \\
\text { members who worked for KPMG. The Inquiry } \\
\text { chaired by advocate Dumisa Ntsebeza held } \\
\text { public hearings and handed its final report to } \\
\text { SAICA in December 2018. Indications are that } \\
\text { the final report will not be made public until all } \\
\text { investigations and disciplinary hearings have } \\
\text { been finalised. }\end{array}$ & - SAICA & - Guptas \\
\hline Bell Pottinger & $\begin{array}{l}2017 \text { investigation } \\
\text { by PRCA. }\end{array}$ & $\begin{array}{l}\text { In 2016, the Guptas appointed British PR } \\
\text { company, Bell Pottinger, who developed and } \\
\text { promoted a campaign that underpinned the RET } \\
\text { and WMC narratives. In 2017, there was an } \\
\text { independent law firm review by Herbert Smith } \\
\text { Freehills resulting in Bell Pottinger's expulsion } \\
\text { from the Public Relations and Communications } \\
\text { Association (PRCA). }\end{array}$ & $\begin{array}{l}\text { - PRCA } \\
\text { - GuptaLeaks } \\
\text { - Ongoing } \\
\text { research } \\
\text { on disinfor- } \\
\text { mation }\end{array}$ & - Guptas \\
\hline
\end{tabular}

